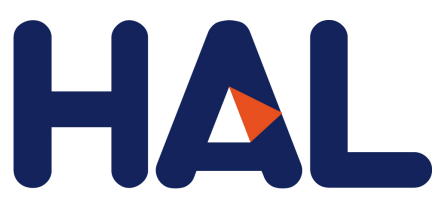

archives-ouvertes

\title{
Alkali pyroxenes and amphiboles: a window on rare earth elements and other high field strength elements behavior through the magmatic-hydrothermal transition of peralkaline granitic systems
}

Cyrielle Bernard, Guillaume Estrade, Stefano Salvi, Didier Béziat, Martin Smith

\section{To cite this version:}

Cyrielle Bernard, Guillaume Estrade, Stefano Salvi, Didier Béziat, Martin Smith. Alkali pyroxenes and amphiboles: a window on rare earth elements and other high field strength elements behavior through the magmatic-hydrothermal transition of peralkaline granitic systems. Contributions to Mineralogy and Petrology, Springer Verlag, 2020, 10.1007/s00410-020-01723-y . hal-02989854

\section{HAL Id: hal-02989854 \\ https://hal.archives-ouvertes.fr/hal-02989854}

Submitted on 5 Nov 2020

HAL is a multi-disciplinary open access archive for the deposit and dissemination of scientific research documents, whether they are published or not. The documents may come from teaching and research institutions in France or abroad, or from public or private research centers.
L'archive ouverte pluridisciplinaire HAL, est destinée au dépôt et à la diffusion de documents scientifiques de niveau recherche, publiés ou non, émanant des établissements d'enseignement et de recherche français ou étrangers, des laboratoires publics ou privés. 
Cyrielle Bernard ${ }^{\mathrm{a}}$, Guillaume Estrade ${ }^{\mathrm{a}}$, Stefano Salvi ${ }^{\mathrm{a}}$, Didier Béziat ${ }^{\mathrm{a}}$, Martin Smith ${ }^{\mathrm{b}}$

${ }^{a}$ GET, CNRS, UPS, Université de Toulouse III, Toulouse, France

${ }^{\mathrm{b}}$ School of Environment and Technology, University of Brighton, Brighton, BN2 4GJ, UK

$\square$ Corresponding author: guillaume.estrade@get.omp.eu

ORCID: 0000-0001-6907-7469

\section{Acknowledgments}

This work was supported by an INSU/TelluS grant from CNRS (French National Center for Scientific Research). We thank Anthony Williams-Jones, Olga Vasyukova and Sam Broom-Fendley for providing some of the rock samples from the Strange Lake and Amis complexes and David Chew who helped with LA-ICP-MS mapping. Kathryn Goodenough provided helpful discussion. We also wish to thank CPM reviewers Charles 7 Beard and Adrian Finch for their suggestions and constructive criticisms, which greatly improved the final

(8)
version of this manuscript.

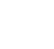

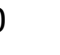


Peralkaline granites and pegmatites are a prime repository of REE and HFSE, critical raw materials. Although it is accepted that magmatic processes are fundamental in concentrating these metals, the role of hydrothermal fluids in concentrating and fractionating these elements remains unclear. This paper investigates the global reproducibility of the magmatic-hydrothermal evolution of alkaline silica-saturated systems using alkali pyroxene and amphiboles from six alkaline complexes. These minerals contain significant amounts of REE and other HFSE, and pyroxene is stable throughout the magmatic and hydrothermal stages. Amphibole consists of mostly unzoned arfvedsonite, leakeite, and katophorite, while pyroxene is always aegirine. Two types of aegirine were defined. In all complexes, type-I aegirine is zoned; its core is enriched in $\mathrm{Ca}, \mathrm{REE}, \mathrm{Zr}, \mathrm{Hf}, \mathrm{Sc}$ and $\mathrm{Sn}$, and the rims in $\mathrm{Na}, \mathrm{Fe}^{3+}$ and contain secondary rare-metal bearing minerals and fluid inclusions. Type-II aegirine replaces amphibole and is oscillatory zoned. We interpret the amphiboles and REE-rich cores of type-I aegirine to have grown during the magmatic stage, whereas the rims of REE-poorer type-I and II aegirine formed during the hydrothermal stage. During magmatic crystallization, REE intake into amphiboles and pyroxene as well as LREE-HREE fractionation were favored by their crystallographic properties and by competition among them and other minerals. During subsequent hydrothermal stages, REE and other HFSE were remobilized, locally reconcentrated and fractionated in mineral pseudomorphs and secondary pyroxene. These observations point out the importance of studying rock-forming minerals such as pyroxenes and amphiboles to unravel geological events controlled by common processes globally.

Keywords

Peralkaline granite, pegmatite, pyroxene, amphibole, rare earth elements, high field strength elements

$\underline{\text { Introduction }}$ 
(Lucas et al. 2014; Goodenough et al. 2018), but their production is quite restricted, worldwide. REE deposits can be primary (igneous, carbonatites and alkaline systems) or secondary (placers and ion-adsorption) (Chakhmouradian and Wall 2012) and economic concentrations of heavy REE (HREE, Gd to Lu) are rather rare compared to those of light REE (LREE, La to Eu). The latter occur in high amounts mostly in carbonatites and placer deposits and are commonly hosted in fluorcarbonates such as bastnäsite-(Ce), parisite-(Ce) and synchysite-(Ce), and phosphate such as monazite-(Ce). Ion-adsorption deposits provide most of the global HREE production (Chakhmouradian and Wall 2012; U. S. Geological Survey 2019). In alkaline igneous rocks, REE are hosted mainly in monazite-(Ce), xenotime-(Y), fergusonite-(Y), loparite-(Ce) and eudialyte-group minerals (EGM) (Larsen and Sørensen 1987; Chakhmouradian and Wall 2012). Most alkaline igneous rocks are silicaundersaturated, with the silica-saturated variety (i.e., granitic) being quite rare (e.g. Larsen and Sørensen 1987; Ranløv and Dymek 1991; Foland et al. 1993; Kramm and Kogarko 1994; Sheard et al. 2012). However, it is the latter that have high $\mathrm{Yb} / \mathrm{La}$ ratios compared to other varieties (Fig 1). Pegmatites, which form from the last and most evolved part of silica saturated melts, concentrate the highest amounts of REE and other HFSE.

There is a general consensus in the literature that magmatic processes play a role for a pre-enrichment of alkaline rocks in REE and other HFSE (Marks and Markl 2017). These include sourcing from undepleted, more or less metasomatized mantle, crustal contamination, fractional crystallization, and melt-melt immiscibility during magma cooling (Bonin 2007; Nardi and Bitencourt 2009; Chakhmouradian and Zaitsev 2012; Veksler et al. 2012). There is also evidence that hydrothermal processes may play a key role in concentrating these elements to ore grades (e.g. Salvi and Williams-Jones 1990; William-Jones et al. 2012). However, to date, the relative importance of magmatic versus hydrothermal processes is still debated, partly because the processes occurring at the magmatic-hydrothermal transition are hard to document and most studies were carried out in the laboratory (e.g. Migdisov et al. 2016).

To fill this gap, it is important to understand the timing of concentration of the REE in natural occurrences. To do so, in this paper we propose for the first time a detailed study of common minerals that carry REE and other HFSE from the magmatic through the hydrothermal stages, from six silica-saturated alkaline occurrences worldwide. The goal is to make out the meaning of textures and link them to the major events that impacted the selected complexes, i.e. the magmatic-hydrothermal transition. Once it is clear which zones of the crystals grew during the magmatic phase and which grew during hydrothermal circulations, we can analyze the REE and other HFSE compositions in the different zones, and infer the timing of concentration and fractionation of the REE. Ideal candidates to do so are the pyroxene and amphibole mineral groups, because of their ubiquitous presence in 
these rocks and because they have been documented to form during a large span of the evolution of alkaline rocks, from early magmatic to late hydrothermal stages (e.g. Nielsen 1979; Jones and Peckett 1981; Ranløv and Dymek 1991; Marks et al. 2004). In addition, they incorporate a relatively high amount of REE and other HFSE compared to other rock-forming minerals (e.g. alkali feldspar and quartz), even though they are not considered as ore as their partition coefficients for HFSE (except Eu) are not high enough (Fedele et al. 2015). Primary zirconosilicates can also incorporate high levels of HFSE and are common in alkaline rocks, however, they are frequently altered to secondary minerals during the hydrothermal stage. Hence, pyroxenes and amphiboles are the best minerals to evidence the behavior of HFSE throughout the entire process of alkaline granite and pegmatite crystallization.

\section{Geological background}

The six alkaline igneous complexes on which this work focuses are: Ambohimirahavavy (Estrade et al. 2014a) and Manongarivo (Donnot 1963) in Madagascar, Amis in Namibia (Schmitt et al. 2002), Evisa in Corsica (Bonin et al. 1978), Khan Bogd in Mongolia (Kovalenko et al. 2006), and Strange Lake in Canada (Currie 1985). These complexes were chosen because all present evidence of hydrothermal circulation and contain high amounts of REE (from $800 \mathrm{ppm}$ in a granite from Khan Bogd to $12 \%$ in a pegmatite from Strange Lake, unpublished data). All complexes contain peralkaline rocks, i.e. their ratio of $\left(\mathrm{Na}_{2} \mathrm{O}+\mathrm{K}_{2} \mathrm{O}\right) / \mathrm{Al}_{2} \mathrm{O}_{3}$ is $>1$. Some of them have been the subject of in-depth studies, such as the Strange Lake complex which was first studied in the late 1980's (e.g. Miller, 1986; Salvi and Williams-Jones 1990) and still is today (Vasyukova and Williams-Jones 2020); others are poorly known, as is the case for the Manongarivo complex, for which the only available information is a mere mention in a French compilation (Donnot, 196즈).

Although they were emplaced in different geodynamic complexes and at different periods, it appears that the melt source was a metasomatized upper mantle for all six complexes. Crustal contamination and feldspars fractionation, if occurring, are two processes that can enrich alkaline granites in REE. However, the rate of partial melting at the origin of these complexes is still debated, which is an essential parameter given that a lower rate implies a greater accumulation of incompatible elements, REE included, in the newly generated melt. All complexes underwent at least one alteration episode from an orthomagmatic fluid, and some of them an additional late hydrothermal event (identified at Amis, Evisa, and Strange Lake). The composition of the fluids that circulated was measured in fluid inclusions at Ambohimirahavavy and Strange Lake, and inferred from the 
study of secondary mineral assemblages for the other complexes. The presence of significant amounts of $\mathrm{Na}^{+}$ and $\mathrm{Fe}^{3+}$ in an orthomagmatic fluid is reported for Evisa, the two Malagasy complexes and Strange Lake, and $\mathrm{Ca}^{2+}$ was identified at Khan Bogd, Madagascar and Strange Lake. Locally, $\mathrm{CO}_{2}$ and/or $\mathrm{CH}_{4}$ were reported at Khan Bogd and Strange Lake, and $\mathrm{CO}_{3}{ }^{2-}$ at Amis. The resulting conclusions are similar for all the complexes: independently of its orthomagmatic or late origin, a F-, Ca-rich fluid is systematically observed and inferred to have mobilized and fractionated the REE. The importance of this process compared to magmatic ones in concentrating and fractionating the REE is still a matter of debate. Comparing six complexes that were emplaced in different geodynamic settings and witnessed different fluid conditions (composition, temperature), is a strategy to highlight common features in order to better constrain and generalize the timing of REE and other HFSE enrichment in alkaline complexes. Below, follows a rapid summary of the main geological features of each complex; more detailed information is provided in Online Resource 1.

\subsection{Amis complex, Namibia}

The Amis complex and the larger Brandberg complex onto which it is juxtaposed are of the same age (132.5 to $130.5 \mathrm{My})$ and are hosted in metasediments of the Damara orogen ( $550 \mathrm{My}$; Miller 1983) and volcanic rocks from the Paraná-Etendeka igneous province. Three granite and 4 pegmatite-aplite samples were used for this study. The Amis complex is mainly made of an arfvedsonite granite and aegirine-rich pegmatite-aplites. The Amis complex is highly enriched in REE, other HFSE and volatiles $\left(\mathrm{H}_{2} \mathrm{O}, \mathrm{F}\right)$. Pegmatites and aplites in the north-western part of the Amis complex are particularly enriched in REE mineralizations and uranium. Schmitt et al. (2002) infer that hydrothermal fluids had a very limited impact on the rocks of Amis complex. They affirm that minerals are all mainly magmatic, with the exception of replacement of arfvedsonite by quartz-hematite overgrowths. Based on the study of melt inclusions, they propose that the main process of REE and other HFSE enrichment is magmatic. In contrast, Diehl (1990) proposed that hydrothermal fluids played a significant role, and inferred the replacement of arfvedsonite by aegirine.

\subsection{Evisa complex, Corsica}

The Evisa complex (290 My; Cocherie et al. 2005) was emplaced among metaluminous granitoids. We collected 7 granite and 5 pegmatite samples from the central part of the complex. The complex mainly comprises hypersolvus (perthitic feldspar) and subsolvus (albitic and alkali feldspar) peralkaline granites (Bonin 1990) and 
associated pegmatites rich in REE-bearing minerals such as monazite-(Ce), apatite, and allanite-(Ce). The hypersolvus granite probably experienced two hydrothermal events: a minor, early episode at the end of crystallization, and a more important second episode, characterized by F-rich fluids, around 200 My (Poitrasson et al. 1998; Bonin et al. 2008). The subsolvus granite is intrusive into the perthitic unit and only experienced the second hydrothermal event, which triggered the replacement of the primary zirconosilicate elpidite by a secondary assemblage (Bonin 1990).

\subsection{Khan Bogd complex, Mongolia}

The Khan Bogd complex is located in the southern Gobi Desert, at the transition between island-arc calc-alkaline differentiated volcanics (329 $\pm 5 \mathrm{My})$ and rift-related bimodal basalt-comendite-alkali granite association (318$290 \mathrm{My}$ ), and is dated at approximately $290 \mathrm{Ma}$ (Kovalenko et al. 2006). It is among the largest alkaline granite plutons in the world, with a surface area of $1500 \mathrm{~km}^{2}$. We collected 3 granite and 7 pegmatite samples, mostly on the western side of the complex. The pluton consists of two ring bodies: a western peralkaline arfvedsonitebearing granite and a later emplaced, eastern aegirine granite. They are both associated with pegmatites. The pluton has been investigated for mining purposes and estimates indicate grades between 0.3 and $4.5 \%$ REE, the highest grade being located at the top of the granite plutons (estimation of the tonnage is not available,

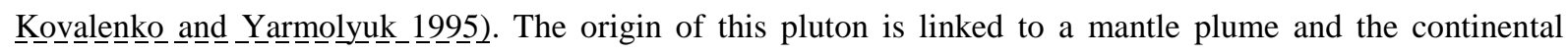
subduction of the South Mongolian Hercynides, but the exact magmatic process is still debated (Kovalenko et al. 2006; Kynicky et al. 2011). Kynicky et al. (2011) propose the release of a silica-saturated orthomagmatic fluid that, similarly to Evisa, triggered the replacement of primary elpidite.

\subsection{Manongarivo and Ambohimirahavavy complexes, Madagascar}

Ambohimirahavavy and Manongarivo are the biggest complexes of the Ampasindava province in northwestern Madagascar, yet are not well documented. They were emplaced at circa 24 Ma into marine-shelf carbonates and marine-fluvial siliciclastic sediments of the Isalo Group (Thomas et al. 2009; Cucciniello et al. 2016). We collected 3 granite and 4 pegmatite samples from the southern part of the Ambohimirahavavy complex. Due to poor outcropping conditions and low occurrence of pegmatites, we could only obtain 3 
pegmatite samples from Manongarivo. The samples from Ambohimirahavavy were selected according to previous studies from Estrade et al. (2014a, b). Both complexes were likely emplaced in a rifting context and are made of two ring-shaped intrusions side by side, composed of nepheline syenite, alkali feldspar syenite, biotite granite, peralkaline pegmatites, and various volcanic rocks. Due to the recent discovery of rare metals in economic concentrations in ion-adsorption clays, the province drew the attention of a mining exploration company (Estrade et al. 2014b). Granite and pegmatite dykes are the most enriched lithologies in REE and other HFSE. An orthomagmatic fluid metasomatized the complexes in the very last stages of magmatic evolution (Estrade et al. 2014b) and caused the replacement of primary zirconosilicates (eudialyte group minerals (EGM) at Ambohimirahavavy, unknown at Manongarivo) by an assemblage of secondary HFSE-bearing minerals (Lacroix 1923; Rakotovao et al. 2009; Estrade et al. 2018).

\subsection{Strange Lake complex, Canada}

The Strange Lake complex was emplaced $1240 \mathrm{My}$ ago into Paleoproterozoic gneisses and quartz monzonite (Miller 1996) and is considered to represent an extension of the Gardar rift in Greenland (Pillet et al. 1989; Boily and Williams-Jones 1994; Siegel et al. 2017a). We chose 3 granite and 4 pegmatite samples which were selected according to previous studies from Salvi and Williams-Jones (1990, 2006; 1995). The Strange Lake complex consists of a hypersolvus granite, while a younger, largely metasomatized transsolvus granite (rare perthite plus two distinct feldspars, previously classified as subsolvus, e.g. Boily and Williams Jones, 1994) surrounds it, forming the majority of the complex (Gysi et al. 2016; Siegel et al. 2017b). These plutons are partially bounded by an outwardly-dipping fracture associated with fluorite and hematite breccia. Two zones of pegmatites have been reported: the Main zone in the center of the complex, and the B zone on the northwestern edge. These magmatic events correlate with a progressive enrichment in REE and other HFSE, from HFSE-poor hypersolvus granite to HFSE-rich transsolvus granite and pegmatites (Miller 1996). Most of the REE are concentrated in the pegmatites. Reserves are estimated at $278 \mathrm{Mt}$ grading $0.93 \% \mathrm{REE}_{2} \mathrm{O}_{3}$ of which $39 \%$ are HREE, and $214 \mathrm{Mt}$ at $0.85 \% \mathrm{REE}_{2} \mathrm{O}_{3}$ in total (Gowans et al. 2017). The complex also contains significant amounts of $\mathrm{ZrO}_{2}, \mathrm{Nb}_{2} \mathrm{O}_{5}$, and $\mathrm{BeO}$. Two main extensive hydrothermal events affected the complex. The first event is attributed to circulation of a hot $\left(\geq 300^{\circ} \mathrm{C}\right)$ orthomagmatic brine consisting of $\mathrm{K}$ - and Na-enriched aqueous and carbonic phases (Salvi and Williams-Jones 2006; Vasyukova and Williams-Jones 2019). The 
second hydrothermal event consists of a cooler fluid $\left(100-200{ }^{\circ} \mathrm{C}\right)$ resulting from mixing of a meteoric fluid and a fluid originating from the granites (Gysi et al. 2016).

\section{Features common to pegmatites and granites from all six complexes}

Pegmatites in all complexes are heterogeneous in texture, i.e. they show mineralogical layering visible from the scale of the outcrop to that of a thin section (Fig 3), whereas granites are generally homogeneous. In pegmatites, the layers have grain sizes ranging from a few $\mu \mathrm{m}$ to about $40 \mathrm{~cm}$ and locally more (Fig 3). Therefore, to obtain meaningful data, samples for this study were selected from zones of relatively fine grain size (less than a few $\mathrm{cm}$ ).

All pegmatites and granites are dominated by quartz, alkali feldspar (perthites, albite, orthoclase, and/or microcline) that are commonly strongly albitized, plus alkali amphiboles and, mostly in pegmatites, aegirine (Fig 4). Common minerals in both rock types include zircon, pyrochlore group minerals (PGM) and Fe- and Tioxides. Other minerals present mostly in pegmatites include $\mathrm{Ca}$ and $\mathrm{Na}$ zirconosilicates, fluorite, astrophyllite and REE-bearing minerals (typically bastnäsite-(Ce), monazite-(Ce), xenotime-(Y), chevkinite-(Ce), allanite$(\mathrm{Ce})$, aeschynite-(Y), fergusonite-(Y), britholite-(Y), synchysite-(Ce)). Ti-bearing minerals such as chevkinite(Ce) and astrophyllite show signs of alteration such as dissolved edges (Fig 4a).

$\mathrm{Ca}$ and $\mathrm{Na}$ zirconosilicates, which are characteristic minerals of agpaitic rocks, are mostly eudialyte-group minerals (EGM) at Ambohimirahavavy (Lacroix 1923; Estrade et al. 2018), and elpidite at Evisa, Khan Bogd and Strange Lake (Bonin 1988; Salvi and Williams-Jones 1990; Grigor'eva et al. 2011). These zirconosilicates were partially to totally replaced by secondary miaskitic mineral assemblages, which commonly form pseudomorphs (Poitrasson et al. 1998; Estrade et al. 2014b; Gysi et al. 2016). The mineralogy of the pseudomorphs varies in the different complexes and consists either of different $\mathrm{Zr}$ - and/or REE-bearing minerals (Fig. 4b), or exclusively zircon plus quartz, i.e. typical miaskitic mineral assemblage (Fig 4c). Both pseudomorph types are found in all complexes, except in Amis where our samples only contain the miaskitic zircon-quartz type. Elpidite can also be extensively replaced by other zirconosilicates, namely armstrongite and gittinsite (e.g. Salvi and William-Jones 1995), whereas EGM is only partially replaced by these phases. At Khan Bogd, cathodoluminescence reveals the elpidite is altered from its core, replaced by zircon and armstrongite (Fig 4d). Pseudomorphs from Evisa consist of Ca-rich mineral assemblages such as fluorite and parisite-(Ce), the 
latter growing mostly at the expense of bastnäsite-(Ce). At Manongarivo and Amis, the precursor mineral has not been identified because partial replacement has not been observed in these complexes, so far.

\section{3. $\quad$ Analytical methods}

Polished thin sections were prepared from all samples from the six complexes and were studied using transmitted light microscopy, cathodoluminescence, Scanning Electron Microscopy (SEM), microprobe, and Laser-Ablation Inductively Coupled Plasma Mass Spectrometry (LA-ICPMS) in order to determine mineral textural relationships and amphiboles and pyroxene zoning.

SEM images in back-scattered electron (BSE) mode were collected with a Jeol JSM6360LV SEM coupled with a Bruker silicon drift detector and interpreted with the Esprit software at the Géosciences Environnement Toulouse laboratory, using an accelerating voltage of $20 \mathrm{kV}$, and a detection time of $40 \mathrm{~s}$.

Mineral compositions were determined at the Centre Raymond Castaing in Toulouse, using a CAMECA SX Five electron microprobe (EPMA), with an accelerating voltage of $15 \mathrm{kV}$, a beam current of $20 \mathrm{nA}$ for pyroxene, $10 \mathrm{nA}$ for amphibole, and a beam diameter of about $2 \mu \mathrm{m}$. Quantitative elemental maps were performed on the same instrument, using an accelerating voltage of $15 \mathrm{kV}$, a beam current of $20 \mathrm{nA}$ and $100 \mathrm{nA}$ for major and minor elements respectively. Counting time was $1 \mathrm{~s}$ on each pixel with a step of 0.5 to $4 \mu \mathrm{m}$ depending on crystal size. Uncertainties were calculated using the method of Ancey et al. (1978). Standards used for calibration as well as detection limits based on repeated measurements are provided in Online Ressource 2.

To resolve the oxidation state of iron measured by microprobe, calculations of the valence were made following Droop (1987). In order to verify these measurements, a ${ }^{57} \mathrm{Fe}$ Mössbauer spectrum was collected at the Laboratoire de Chimie de Coordination - University of Toulouse on a constant-acceleration conventional spectrometer, at $80 \mathrm{~K}$ and with a $1.85 \mathrm{GBq}$ source of $57 \mathrm{Co}$, over a $\pm 12 \mathrm{~mm} / \mathrm{s}$ range with 512 channels. The spectra were acquired via a compact detector c-system and recorded with a Canberra multichannel analyzer, coupled to a computer with Recoil Mossbauer Analysis Software 1.05 from Lagarec and Rancourt (1997). Uncertainties were calculated using the covariance matrix. Pyroxene end-members were then calculated following Mann et al. (2006). Amphiboles end-members were calculated using the spreadsheet available from Locock (2014). 
Trace element concentrations were determined in situ by LA-ICPMS at the Géosciences Environnement Toulouse laboratory, University of Toulouse, on 30- $\mu \mathrm{m}$ polished thin-sections, using a New Wave Research ESI 213 laser coupled to a Thermo-Fisher Element-XR high-resolution ICP-MS. Laser beam diameter varied from 30 to $50 \mu \mathrm{m}$ depending on mineral size, and data were acquired by ablating lines instead of spots in order to prevent intersecting solid inclusion or internal zoning. NIST synthetic glass certified reference materials SRM 610 and SRM 612 were used as external and quality control standards, respectively. Each analysis was normalized using $\mathrm{SiO}_{2}$ values previously determined by EMPA. The relative precision ranged from 5 to $10 \%$ and detection limits, based on repeated measurements, are provided in Online Ressource 3. Trace elements maps were performed at the Trinity College in Dublin according to the method provided in U_bide e $\underline{\text { t }}$ al $\underline{\text { l. }}$ (2015) using photon machines G2 193 nm UV laser with a Helex two-volume cell coupled to a Thermo iCAPQ ICP-MS. Laser beam spot for maps was $12 \mu \mathrm{m}$ square, scan speed $8 \mu \mathrm{m} / \mathrm{s}$ and repetition rate $41 \mathrm{~Hz}$. NIST SRM 610 glass was used as standard. A beam size of $12 \mu \mathrm{m}$ square typically allows a spatial resolution of 7-10 $\mu \mathrm{m}$ in $\mathrm{x}$ and $\mathrm{y}$. This relatively new ablation technique removes only 3-4 $\mu \mathrm{m}$ of material, which allows several maps to be performed on the same area. A first map with all REE and other HFSE was first established, before acquiring a second map with only 5 elements in order to obtain a better signal. LA-ICP-MS maps provide detailed spatial information on zonation in crystals that would not be available otherwise. Analysis were semi-quantitative and compared to microprobe data to obtain the real concentration.

To check for the absence of REE mineral inclusions in the pyroxene, we analyzed one sample from the Amis complex by Scanning Transmission Electron Microscopy (STEM) at the Centre Raymond Castaing in Toulouse. Unlike TEM, with STEM the electron beam is focused on a specific point of the sample and scans its surface instead of being focused on the entire surface. This allows a better resolution as well as local chemical identification (e.g. Pennycook for STEM. The FIB is a Hélios 600i operated at $5 \mathrm{kV}$, and the TEM a JEOL cold-FEG JEM-ARM200F operated at $200 \mathrm{kV}$ equipped with a Cs probe corrector reaching a spatial resolution of $0.078 \mathrm{~nm}$. Images were acquired in high-angle dark field (HAADF) as well as bright field (BF) modes. EDX spectra were recorded on a JEOL CENTURIO SDD detector.

\section{Amphibole and pyroxene textural and chemical description}

\subsection{Textural features}


283

Amphiboles occur in granites and pegmatites as well-developed euhedral crystals (Fig 4e). No significant textural difference was found between amphiboles of the six complexes. They all appear pleochroic, dark green or dark blue to black under plain polarized light (PPL). Their size is highly variable from one complex to another as well as inside pegmatites (typically ranging from $20 \mu \mathrm{m}$ to $10 \mathrm{~cm}$ ), but is always comparable with the size of quartz and alkali feldspar crystals in the same rock. Except at Evisa (Fig 4j), amphiboles are not zoned, but they display dissolution/corrosion textures on their rims. They commonly have small quartz and feldspar inclusions, and are in equilibrium with these minerals. Replacement of amphiboles by aegirine and Ti- and/or Fe-oxides is a common feature of peralkaline granitoids (Marks and Markl 2017) and occurs in all pegmatites and some granites (Fig 4e).

\subsubsection{Pyroxene}

Pyroxene is ubiquitous in pegmatites and granites of all six complexes but present three different textural features. (1) In pegmatites which contain only minor amphibole, it occurs as light to dark green euhedral crystals under PPL ranging from $50 \mu \mathrm{m}$ to $10 \mathrm{~cm}$. These pyroxene crystals present a core-to-rim zonation pattern, with additional sector zoning in the rims, which are visible under PPL (Fig 4f). Similarly to amphiboles, these crystals are in equilibrium with quartz and alkali feldspar grains. In the rims of this pyroxene, we also found fluid inclusions (Fig 4g) and mineral inclusions that match the composition of those met in pseudomorphs (Fig $4 \mathrm{~b}$ and h). These pyroxene crystals were found in all studied complexes but Strange Lake. At Khan Bogd, these crystals present an additional zoning area between the core and the sector zoned rims (Fig 4k). (2) In some pegmatites, pyroxene occurs as anhedral crystals of size similar to the one we just described. These crystals are oscillatory zoned, from yellowish to green under PPL (Fig 4i). They commonly include Fe- and/or Ti- oxides. (3) In granites as well as in some pegmatites, anhedral pyroxene is found replacing amphibole (Fig 4e). This pyroxene is also weakly oscillatory zoned. As it replaces amphibole only partially, it's size is smaller than the previously described pyroxene crystals and depends on the original amphibole size. This pyroxene is associated with $\mathrm{Fe}$ - and/or Ti- oxides and can sometimes keep the $120^{\circ}$ cleavages from the original amphibole.

Based on occurrence, size, color, zoning and mineralogical associations, we distinguish two main types of pyroxene in the six complexes we focus on in this study. Type-I matches euhedral zoned pyroxene, and our study focuses mainly on this type. Based on the observation that they present anhedral shape, oscillatory zoning, 
and are associated with $\mathrm{Fe}$ - and/or Ti- oxides, we regroup anhedral single pyroxene crystals and pyroxene replacing amphibole under the denomination type-II.

\subsection{Major element composition}

\subsubsection{Amphiboles}

Since they present the same textural features, all amphiboles were identified based solely on their chemistry, following the classification of Hawthorne et al. (2012) and in accordance with Leake et al. (1997). The general formula of amphibole is $\mathrm{AB}_{2} \mathrm{C}_{5} \mathrm{~T}_{8} \mathrm{O}_{22} \mathrm{~W}_{2}$ where, in this study, $\mathrm{A}=\mathrm{Na} ; \mathrm{B}=\mathrm{Na}, \mathrm{Ca}$; $\mathrm{C}=\mathrm{Fe}^{2+}, \mathrm{Fe}^{3+}$, $\mathrm{Li} ; \mathrm{T}=\mathrm{Ca}, \mathrm{Al}$; and $\mathrm{W}=\mathrm{OH}, \mathrm{F}$. The rootname is given to these amphiboles based on the composition of the sites $\mathrm{A}, \mathrm{B}$ and $\mathrm{C}$, and the prefix is added according to the composition of the sites $\mathrm{C}$ and $\mathrm{W}$. By strictly following these rules, it appears that some complexes contain only one amphibole type, common to granites and pegmatites, and some contain different amphiboles (Table 1). Ambohimirahavavy (ferro-ferri-fluoro-leakeite; $\mathrm{Na}_{3} \mathrm{Fe}_{4} \mathrm{LiSi}_{8} \mathrm{O}_{22} \mathrm{~F}_{2}$ ), Manongarivo and Strange Lake (fluoro-arfvedsonite; $\mathrm{Na}_{3} \mathrm{Fe}_{5} \mathrm{Si}_{8} \mathrm{O}_{22} \mathrm{~F}_{2}$ ), and Khan Bogd (arfvedsonite; $\mathrm{Na}_{3} \mathrm{Fe}_{5} \mathrm{Si}_{8} \mathrm{O}_{22}(\mathrm{~F}, \mathrm{OH})_{2}$ ) contain only one amphibole. At Amis, amphibole is ferro-ferri-fluoroleakeite in pegmatites and fluoro-arfvedsonite in the granite. At Evisa, granites and pegmatites contain a zoned amphibole with a core of fluoro-arfvedsonite and a rim of ferro-ferri-fluoro-leakeite (Fig 4L). In addition, the hypersolvus granite from Evisa contains zoned crystals with ferro-ferri-katophorite $\left(\mathrm{Na}_{2} \mathrm{Ca}\left(\mathrm{Fe}^{2+}, \mathrm{Mg}\right)_{4} \mathrm{Fe}^{3+}\left(\mathrm{Si}_{7} \mathrm{Al}\right) \mathrm{O}_{22}(\mathrm{OH})_{2}\right)$ in their core and fluoro-arfvedsonite in their rims (Fig $\left.4 \mathrm{j}\right)$.

However, it is important to keep in mind that amphibole is a solid solution, thereby two amphiboles can have different names but be close in composition, and inversely can have the same name but present a compositional range. To avoid these artificial hiatuses and subsets, we focused on the concentration of elements involved, when attributing amphibole names in this study. Hence, the distinction between katophorite and other amphiboles is based on the $\mathrm{Ca} /(\mathrm{Ca}+\mathrm{Na})$ ratio; being $>0.25$ (close to 0.4 ), this makes it a Na-Ca amphibole, compared to values $<0.1$ for other amphiboles, which are then considered Na-amphiboles. Thereby, ferro-ferrikatophorite at Evisa exhibits a significant compositional gap with the other amphiboles from this study. The distinction between Na-amphiboles is more subtle, and is based on the amount of $\mathrm{Li}$ and $\mathrm{Fe}^{2+} / \mathrm{Fe}^{3+}$ ratio in the $\mathrm{C}$ site. Ideally, leakeite has $1 \mathrm{Li}$ apfu; this value is on average 0.6 apfu at Ambohimirahavavy and Evisa, and 0.7 apfu at Amis. Arfvedsonites from the other complexes have average Li contents of 0.1-0.3 apfu, validating the distinction proposed here, although these values are intermediate between the two categories. The prefixes ferro- 
and ferri- refer to the presence of $\mathrm{Fe}^{2+}$ and $\mathrm{Fe}^{3+}$, respectively, in the $\mathrm{C}$ site.The prefix fluoro- indicates that the $\mathrm{F}$ concentration is systematically higher than the concentration of other elements in the W site. In this study, the amounts of $\mathrm{F}$ and $\mathrm{OH}$, respectively, are close to 1.1 and 0.9 apfu in arfvedsonite from all complexes but Khan Bogd, where it is closer to 0.9 apfu F and 1.1 apfu OH. Strictly complying with the definition would result in two different names ( $\mathrm{F}$ and $\mathrm{OH}$ varieties), which would vary with each complex. However, this would lead to add unnecessary confusion to the nomenclature, therefore, because the compositional differences are only minor, we chose to ignore this parameter.

Within a given category, amphiboles are globally similar in composition in all complexes, including $\mathrm{Fe}^{2+} / \mathrm{Fe}^{3+}$ (around 3 for fluoro-arfvedsonite, 2 for leakeite, and 3.5 for katophorite), with only local variations (Table 1). Chlorine was not detected by microprobe analyses in any of the amphiboles. The main distinction regarding major element composition is found in (fluoro)-arfvedsonite from Manongarivo and Khan Bogd, which both have high contents of Mn (respectively 1.92 and $1.66 \%$ vs $0.50 \%$ in the other complexes, Fig 5d) and $\mathrm{Fe}^{2+} / \mathrm{Fe}^{3+}$ (4.00 and 5.90 vs 2.40). Amphibole from Ambohimirahavavy is also rich in Mn (1.99\%) but does not show a high $\mathrm{Fe}^{2+} / \mathrm{Fe}^{3+}$ value. Fluoro-arfvedsonite from Amis is as rich in $\mathrm{F}$ as ferro-ferri-fluoro-leakeite from all other complexes (around $1.6 \mathrm{apfu}$ ), which is unusual (Deer et al. 1997b). Amphiboles from pegmatites are generally slightly richer in HFSE, $\mathrm{Li}$ and $\mathrm{Fe}^{3+}$ than amphiboles from granites.

Based on composition, pyroxene in granites and pegmatites consists of 85 to $97 \%$ aegirine endmember. Therefore, according to the classification of Morimoto (1988), we will refer to it as aegirine in the following sections of this paper. Pyroxene from Ambohimirahavavy and Khan Bogd is more Ca-rich than the other complexes, but it is still classified as aegirine.

Type-I aegirine crystals show a characteristic zoning pattern in pegmatites from all locations: a core-torim zoning visible in BSE images (Fig 6n) and a sector zoning visible even by optical microscopy (Fig 6o). This pattern defines 3 main zones, where zone A is the core and zones $\mathrm{C}$ and $\mathrm{D}$ form sector-zoned rims. Zone $\mathrm{C}$ matches the crystallographic sector (110), and zone D sector (100) (Ubide et al. 2019). In a few cases, an additional zone matching the crystallographic sector (010) is also present (e.g. ESM 6). All zones are optically distinguished by different tones of green, attributed to different Ti contents (Fig 6g) (e.g. Strong 1969; Ferguson 1973; Nielsen 1979). The contacts between different zoning are sharp in all occurrences (Fig 6). Zone A, the 
core, is systematically enriched in $\mathrm{Ca}, \mathrm{Sn}, \mathrm{Hf}, \mathrm{Zr}$ (Fig 7a, b, c, g) and depleted in $\mathrm{Na}, \mathrm{Al}$ and $\mathrm{Fe}^{3+}$ compared to the other zones (Table 3). In pegmatites, we measured up to $2 \mathrm{wt} \% \mathrm{ZrO}_{2}$ in aegirine cores; although uncommon, Zr-rich aegirine was also described in other localities such as in nepheline syenites from the Motzfeldt Centre, South Greenland (Jones and Peckett 1981; up to $7 \mathrm{wt} \% \mathrm{ZrO}_{2}$ ) and in metaluminous trachytes from the Warrumbungle Volcano, Australia (Duggan 1988; up to $14.5 \mathrm{wt} \% \mathrm{ZrO}_{2}$ ). Sector zone C is particularly enriched in $\mathrm{Ti}$ and $\mathrm{Ca}$ (Fig 6e, g), while D is in Fe (Fig 6c). Two major growth layers are visible in the rims with, in sector $\mathrm{C}$, $\mathrm{Ti}$ and $\mathrm{Ca}$ decreasing towards the rims of each layer (Fig 6e, g). Al content is low in aegirine from all six complexes (about $0.3 \% \mathrm{Al}_{2} \mathrm{O}_{3}$ compared to standard average values of $1.2 \%$ reported in aegirine; e.g. Deer et al. 1997a). At Khan Bogd, an additional zone, referred to as zone B, is found between the core and the sectorzoned rims of the crystals (Fig 4k); it shows random oscillations due to variations in many elements, including Ti and Mn. The same zoning pattern, including zone B, was also observed by Ranløv and Dymek (1991) in nepheline syenite from the Narssaq Peninsula. However, they only documented variations in $\mathrm{Zr}, \mathrm{Ti}, \mathrm{Al}, \mathrm{Na}, \mathrm{Ca}$ and Fe. Larsen (1976) and Piilonen et al. (1998) respectively described a core-to-rim zoning in aegirine from nepheline syenite in the Ilímaussaq and Mont Saint-Hilaire complexes. They report cores enriched in $\mathrm{Ca}, \mathrm{Fe}^{2+}$, $\mathrm{Mg}, \mathrm{Mn}$ and $\mathrm{Zr}$ compared to rims, which in turn contain higher $\mathrm{Al}, \mathrm{Ti}, \mathrm{Na}$ and $\mathrm{Fe}^{3+}$. Shearer and Larsen (1994) supplemented the description of aegirine from Ilímaussaq, by reporting $\mathrm{Sr}$ and REE enrichment in cores compared to rims. In our analyses, we did not observe a systematic difference in $\mathrm{Mn}$ and $\mathrm{Sr}$ contents between core and rims.

Type-II aegirine is not sector-zoned but shows oscillatory zoning and we observed a wide variety of compositions depending on which layer was analyzed (Table 2). This zoning is irregular, with no core, made of compositionally varying layers with variable thickness. No common pattern was found among any type-II aegirine crystals, beside their heterogeneity. Many elements are involved, including $\mathrm{Fe}, \mathrm{Mn}, \mathrm{Ca}$, and $\mathrm{Ti}$ (see Online Resource 8). No significant chemical differences were found between type-II aegirine from granites and pegmatites. Type-II aegirine is commonly depleted in $\mathrm{Ti}$ and $\mathrm{Sn}$ compared to type-I aegirine, except at Khan Bogd. Mg is commonly found in higher concentration in type-II aegirine (Table 2). No significant compositional difference was found between type-II aegirine replacing amphibole in granite and those in pegmatites. At Strange Lake, all observed aegirine crystals are of type-II (Table 2; Salvi and Williams-Jones 1990; Roelofsen 1997). 
Amphiboles from all six complexes have very similar trace element patterns (Table 1). Fluoroarfvedsonite and ferri-fluoro-leakeite have practically the same composition, with Li contents alone being responsible for the transition from one kind to the other. This cation enters the amphibole structure according to the substitution: ${ }^{\mathrm{C}} \mathrm{Li}^{+}+{ }^{\mathrm{C}} \mathrm{Fe}^{3+}=2^{\mathrm{C}} \mathrm{Fe}^{2+}$, described by Hawthorne et al. (1996). Ferro-ferri-katophorite, which is more calcic than the two other amphiboles, relates to fluoro-arfvedsonite through the substitution: ${ }^{\mathrm{B}} \mathrm{Ca}^{2+}+{ }^{\mathrm{T}} \mathrm{Al}^{3+}$ $={ }^{\mathrm{B}} \mathrm{Na}^{+}+{ }^{\mathrm{T}} \mathrm{Si}^{4+}$ (Deer et al. 1997b). This last substitution increases the size of the C site, leaving more space to incorporate LREE. Similarly, the coupled substitution $\left(\mathrm{Mg}, \mathrm{Fe}^{2+}\right) \rightarrow \mathrm{Fe}^{3+}$ occurring in the $\mathrm{C}$ site of amphiboles enhances HREE incorporation (Bottazzi et al. 1999; Siegel et al. 2017b). Amphibole chondrite-normalized REE patterns are systematically enriched in HREE relative to LREE, with a depression in medium REE (MREE, from Eu to Dy). This pattern is unusual compared to more Ca-rich amphibole compositions in which REE patterns are usually enriched in LREE or in MREE (e.g. Marks et al. 2004; Coint et al. 2013). All spectra display a negative Eu anomaly suggesting early plagioclase fractionation (Fig 8). The absolute REE concentrations, though somewhat varying from one complex to another, are quite similar (Fig 8).

Despite their similar patterns, the absolute concentrations of REE and other HFSE can vary in amphiboles from one complex to the other. Fluoro-arfvedsonite from Manongarivo and Khan Bogd both have low quantities of Sn (4 and $10 \mathrm{ppm}$ ) and HREE (35 and $50 \mathrm{ppm}$ on average). Fluoro-arfvedsonite from Manongarivo also has less LREE than fluoro-arfvedsonite from other complexes (11 vs $60 \mathrm{ppm}$ on average). Ferro-ferri-katophorite from Evisa displays high enrichments in LREE and HREE (respectively 224 and 290 ppm) (Fig 8). Ferro-ferri-fluoro-leakeite from Amis is notably different from other complexes in terms of trace elements: it is richer than ferro-ferri-fluoro-leakeite from other complexes in $\mathrm{Ti}(0.18$ vs $0.07 \mathrm{apfu}), \mathrm{Sn}$ ( 360 vs 32 ppm), Zn (0.24 vs 0.05 apfu), Pb (97 vs 7 ppm), LREE (168 vs 37 ppm on average) and HREE (140 vs 83 ppm on average) (Table 1, Fig 5d). Mn and Zn vary together on a 1:1 relation at Strange Lake, as mentioned in the paper by Hawthorne et al. (2001). Mn and Zn covary in amphiboles from Ambohimirahavavy and Amis as well, but in a different way (respectively 4:1 and 1:3), while at Manongarivo and Khan Bogd they do not appear to be related. 
Type-I aegirine, similarly to amphiboles, presents comparable trace elements patterns but different absolute concentrations, from one complex to the other (Table 2). Cores of type-I aegirine from the two Malagasy complexes have high $\mathrm{Zr}$ concentrations compared to other complexes (> 8000 vs $2700 \mathrm{ppm}$ on average for the other complexes). Khan Bogd aegirine is poorer in Li (17 vs 115 ppm), LREE (12 vs 80 ppm on average) and HREE (21 vs 125 ppm on average). Type-I aegirine from Amis, similarly to ferro-ferri-fluoro-leakeite in this complex, shows quite a different trace chemistry than aegirine from other complexes. Average Li is low (50 vs 115 ppm), while other metals are high, e.g. Zn (1780 vs 435 ppm), Sn (3740 vs 700 ppm), $\mathrm{Pb}$ (39 vs 7 ppm) and U (29 vs 0.5 ppm) (Table 2 and Fig 7g). REE and Sc contents in cores of type-I aegirine (zone A) are higher than in the rims (zones B, C and D) for all complexes (Fig 6, 9 and Table 3; similar maps of aegirine crystals from each complex are provided in Online Resource 4 to 8). Inside the rims, sector zone $\mathrm{C}$ is systematically enriched in REE compared to sector D (Fig 6k, 1, m). Nb and Ta do not have a constant behavior: their contents can be higher in sector zone $\mathrm{C}$, be present only in fractures, or be enriched in an independent zonation, with all three cases being possible within the same sample. Similarly to amphiboles, the chondrite-normalized REE patterns of aegirine show high values for HREE relative to LREE, with lower medium REE. This particular pattern is known to be specific to Na- and Fe-enriched aegirine (Mahood and Stimac 1990; Shearer and Larsen 1994). The absolute REE concentrations, are quite similar from one complex to another, although small variations do exist (Fig 9).

Trace element concentrations in type-II aegirine are highly dependent on the zoning pattern. This is notably true for Sn, Hf and Zr. Compared to type-I aegirine, Sn covaries with Ti instead of Zr. The shape of type-II aegirine REE patterns is similar to that of type-I, i.e. high HREE relative to LREE, with a depression in medium REE and a negative Eu anomaly. There is no common pattern in the REE contents of type-II aegirine: REE contents are higher in type-II than in type-I aegirine at Khan Bogd, generally lower at Evisa, and have similar values in Madagascar and at Amis (Fig 7g).

To verify that the concentrations of REE measured in aegirine truly result from their incorporation in the crystal structure and not from small mineral inclusions, we used a STEM approach to investigate the core of a type-I aegirine, where REE are most concentrated. We did not detect any REE mineral inclusion, validating the premise that the REE are indeed incorporated in the pyroxene's structure. The main substitution involved in this process is common to type-I aegirine from all pegmatites. The classic aegirine substitution is 
However, in aegirine from this study there is not enough $\mathrm{Fe}^{3+}$ to equilibrate this reaction, hence $\mathrm{Al}, \mathrm{Zr}$ and $\mathrm{Ti}$, present in aegirine, also contribute to compensate this deficiency, resulting in a new substitution mechanism:

However, REE can enter both M1 and M2 sites along with $\mathrm{Fe}^{3+}$ and $\mathrm{Na}^{+}$(Beard et al. 2019). In clinopyroxenes, incorporation of REE, as well as other HFSE, is controlled by five crystal-chemistry driven mechanisms, with site parameters being determined by the size of the major elements. The first mechanism is decreasing temperature and increasing melt alkalinity, which usually lowers the REE compatibility. The second mechanism is similar to that for amphiboles and is defined by the substitution $\mathrm{Ca} \rightarrow \mathrm{Na}$, which increases the size of the M2 site leaving more space to incorporate LREE. It also decreases the size of the M1 site, making it more adequate to incorporate HREE. The third mechanism takes place in the M1 crystallographic site, where the combined substitution $\left(\mathrm{Mg}, \mathrm{Fe}^{2+}\right) \rightarrow \mathrm{Fe}^{3+}$ leads to a charge effects that allows more HREE to enter this site along with $\mathrm{Fe}^{3+}$ (Marks et al. 2004; Beard et al. 2019). The fourth mechanism, described by Mollo et al. (2017), is also due to a charge effect. These authors propose the coupled substitution REE in the M2 site. In addition, the growth from an environment rich in REE can result in incorporation of high levels of REE in aegirine. Indeed, the adsorption of REE onto aegirine surface during supersaturation may be too fast to equilibrate as crystal growth rate exceeds the internal diffusion rate (Smith et al. 2004).

All of the above mechanisms have the potential of favoring the incorporation of REE into pyroxene, however, aegirine in our study having low ${ }^{\mathrm{T}} \mathrm{Al}$ and practically no $\mathrm{Mg}$ or $\mathrm{Fe}^{2+}$ in the $\mathrm{M} 2$ site, the mechanism of Mollo et al. is probably not significant in this case. The high REE concentration in aegirine of this study is therefore probably the result of the four other mechanisms that rely on size, charge, and kinetics effect at $\mathrm{M}$ sites of aegirine.

\subsubsection{Ce anomalies} Amis, display a peak in Ce concentration (Fig 8 and 9). The occurrence of this peak being restricted to a few samples, mass interference is excluded. In addition, ICP-MS signals showing peaks during ablation were all 
excluded so the presence of this Ce peak is not due to mineral inclusions. This peak may be due to the presence of $\mathrm{Ce}^{4+}$ instead of the usual $\mathrm{Ce}^{3+}$. Indeed, $\mathrm{Ce}^{4+}$ has a smaller ionic radius $(0.97 \AA)$ than $\mathrm{Ce}^{3+}(1.143 \AA)$ for an eight-fold coordination, thereby $\mathrm{Ce}^{4+}$ substitutes more easily with $\mathrm{Fe}^{2+}(0.92 \AA)$ and $\mathrm{Mg}^{2+}(0.89 \AA$; Shannon 1976). The change in oxidation state is commonly interpreted to indicate an increase in oxygen fugacity in the environment that can be either low temperature magmatic $\left(<600^{\circ} \mathrm{C}\right.$, Trail et al. 2012) or hydrothermal (Xu et al. 2017).

\section{Discussion}

\subsection{Origin of amphiboles}

In the previous sections we have seen that three different amphiboles can be distinguished based on their major and trace chemistry: fluoro-arfvedsonite $\left(\mathrm{Na}_{3} \mathrm{Fe}_{5} \mathrm{Si}_{8} \mathrm{O}_{22}(\mathrm{~F}, \mathrm{OH})_{2}\right)$, ferri-fluoro-leakeite $\left(\mathrm{Na}_{3} \mathrm{Fe}_{4} \mathrm{LiSi}_{8} \mathrm{O}_{22} \mathrm{~F}_{2}\right)$, and ferro-ferri-katophorite $\left(\mathrm{Na}_{2} \mathrm{Ca}\left(\mathrm{Fe}^{2+}, \mathrm{Mg}\right)_{4} \mathrm{Fe}^{3+}\left(\mathrm{Si}_{7} \mathrm{Al}\right) \mathrm{O}_{22}(\mathrm{OH})_{2}\right)$. All of them occur in granites and pegmatites as euhedral crystals and contain inclusions of quartz and feldspar grains (Fig 4e), suggesting co-crystallization. Only amphiboles from Evisa have a variable composition, from fluoroarfvedsonite or ferro-ferri-katophorite in cores, respectively to ferri-fluoro-leakeite or fluoro-arfvedsonite in the rims. In the other complexes, only one amphibole type is present in granites and in pegmatites. Based on textural observations, we believe these changes are the sign of magmatic evolution. Indeed, the concentration of Li and $\mathrm{Na}$ rises in the melt as differentiation occurs, until Li- and Na-rich amphiboles crystallize instead of their Lipoor, Mg-, Ca-rich equivalents. Based on various pieces of evidence, such as having a similar age to that of granite emplacement (Kovalenko et al. 2006), presence of melt inclusions (Schmitt et al. 2002), occurrence as well-developed euhedral crystals, and dissolution/corrosion textures (Estrade et al. 2014a; Gysi et al. 2016), it is accepted in the literature that amphiboles are magmatic phases in peralkaline granites. Hence, in accordance with our observations and those in the literature about the six studied complexes, we conclude that amphiboles of all types in our samples are magmatic. Their variation in trace element composition is directly linked to the environment they grew in, a highly evolved melt, enriched in incompatible elements. Among incompatible elements are the REE, which are known to be preferentially incorporated in alkaline amphiboles along with $\mathrm{Na}$ for LREE and $\mathrm{Fe}^{3+}$ for HREE (Bottazzi et al. 1999; Siegel et al. 2017b). Due to this crystallo-chemical control, amphiboles can incorporate a lot of REE at the magmatic stage, with a preference for HREE. Slight compositional differences in $\mathrm{REE}, \mathrm{Zn}, \mathrm{Sn}, \mathrm{Nb}, \mathrm{Zr}$ and $\mathrm{Pb}$ between amphiboles of the 6 complexes (Fig 5d) likely 
reflect parental melt compositions. For example, the presence of ferro-ferri-katophorite in Evisa probably indicates an effect of melt contamination in $\mathrm{Ca}$ by the surrounding aluminous granites.

As previously described, amphiboles are commonly altered to Fe- and Ti-oxides and to type-II aegirine. Based on textural evidence that at Strange Lake this replacement occurs preferentially along cleavages in altered granites and pegmatites, as well as on mass-balance calculations, Salvi and Williams Jones (1990) identified this pyroxene occurrence as hydrothermal. Because we observed this replacement in all of our samples, it follows that a late hydrothermal event is a common feature in the complexes studied and, by extrapolation, most likely in alkaline rocks in general; indeed, a hydrothermal event was also documented in silica-undersaturated alkaline

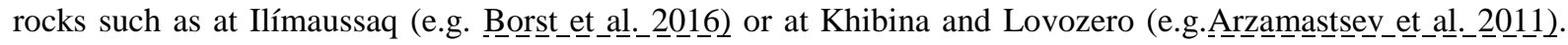
Gysi et al. (2016) and Vasyukova and Williams-Jones (2019) show that at Strange Lake this event is due to a relatively high temperature, Ca-rich fluid. Based on the similarity of amphiboles alteration in all six complexes, we infer that the circulation of an orthomagmatic fluid is a process common to all complexes.

\subsection{Origin of pyroxene}

\subsubsection{Core-to-rim zonation}

Even though both types of aegirine identified in all complexes show some kind of zonation, only type-I shows a core-to-rim zonation, with a core enriched in $\mathrm{Ca}, \mathrm{Zr}, \mathrm{Sn}, \mathrm{Hf}, \mathrm{Sc}, \mathrm{REE}$ and depleted in $\mathrm{Na}, \mathrm{Al}$ and $\mathrm{Fe}$ compared to the rims (Fig 6). The rims also have a higher $\mathrm{Fe}^{3+} / \mathrm{Fe}^{2+}$ ratio than the core. This pattern is systematic for type-I aegirine crystals from all complexes. Type-II aegirine is oscillatory zoned and can replace amphibole.

The sharp compositional change between the core and the rims in type-I aegirine (Fig 6) suggests a sudden change in the crystallizing environment. Based on the scarce presence of type-I aegirine where amphiboles are present, we infer that they grew in competition. Only the rims $\mathrm{C}$ and $\mathrm{D}$ contain fine oscillatory zoning (e.g. $\mathrm{TiO}_{2}$ on Fig 6g), fluid inclusions (Fig 4g), and, at Ambohimirahavavy, mineral inclusions that match the composition of those measured in hydrothermal pseudomorphs (e.g. zircon, bastnäsite-(Ce), Fig 4b and h). Therefore, we infer that type-I aegirine has a magmatic core (zone A on Fig 6p) while the rims are hydrothermal (zones C and D in Fig 6p). Zone B being only present at Khan Bogd, it will be discussed lower in this section. Chemical zoning in aegirine of our rocks matches that observed by Piilonen et al. (1998) in aegirine from Mont 
541

542

543

544

545

546

547

548

549

550

551

552

553

554

555

556

557

558

559

560

561

562

563

564

565

566

567

568

569

570

Saint-Hilaire, which they describe as a magmatic pyroxene overgrown by hydrothermal fibrous aegirine. More details about each element in the different zones is provided in the following paragraphs.

The variations in $\mathrm{Na}, \mathrm{Ca}, \mathrm{Al}$, and $\mathrm{Fe}$ can be explained by a common process. Type-I aegirine magmatic cores are enriched in $\mathrm{Ca}$, and its hydrothermal rims are richer in $\mathrm{Na}, \mathrm{Al}$ and $\mathrm{Fe}^{3+}$. Evidence such as widespread feldspar albitization, fluid inclusions composition, and the hydrothermal growth of aegirine without amphibole indicate that circulating hydrothermal fluids are oxidizing (above the magnetite-hematite buffer), of relatively high pH and rich in $\mathrm{NaCl}$ among other phases (Salvi and Williams-Jones 1996; Smith 2007; Estrade 2014; Gysi et al. 2016). Depletion in $\mathrm{Ca}$ and enrichment in $\mathrm{Na}$ and $\mathrm{Fe}$ while moving on from aegirine magmatic core to hydrothermal rims can then be explained by intake of $\mathrm{Na}$ from the hydrothermal fluids and simultaneous crystallization of Ca-rich secondary minerals in the pseudomorphs (fluorite, bastnäsite-(Ce)). This process increases the amount of aegirine endmember compared to hedenbergite endmember which, along with the hydrothermal environment being more oxidizing than the silicate melt, increases the $\mathrm{Fe}^{3+} / \mathrm{Fe}^{2+}$ ratio in the rims. The absolute amount of $\mathrm{Al}$ is very low in aegirine of this study, so the observed increase in this element in aegirine rims can be linked only to charge effects, with $\mathrm{Al}^{3+}$ being incorporated along with $\mathrm{Fe}^{3+}$.

Because of their similar behavior, $\mathrm{Zr}$ and $\mathrm{Hf}$ both occur in the same growth zones. Based on the many arguments in favor of a magmatic core and hydrothermal rims, we propose two hypotheses as to the crystallization timing of type-I aegirine. Jones and Peckett (1981) asserted that formation of Zr-enriched aegirine is enhanced by low oxygen fugacity, and can only occur if no other Zr-bearing phase is growing. Pseudomorphs after primary zirconosilicates were found around aegirine crystals (Fig $4 \mathrm{~b}$ ), hence it is impossible that aegirine grew after the magmatic zirconosilicates. Our first hypothesis is that, in accordance with the observations made by Jones and Peckett (1981), type-I aegirine cores grew before magmatic zirconosilicates, in the magma chamber. In the absence of any mineral $\mathrm{Zr}$ has a strong affinity for, $\mathrm{Zr}$ partitioned mostly into aegirine. These primary phenocrysts were brought into pegmatites, where primary zirconosilicates began to crystallize, incorporating most of the available Zr.. Moving on to the hydrothermal stage, primary zirconosilicates were destabilized and replaced by minerals richer in $\mathrm{Zr}$, including zircon, which form the pseudomorphs. Aegirine rims were then in competition with zircon, which has a high $\mathrm{Zr}$ uptake and therefore accounts for the decrease in $\mathrm{Zr}$ concentration in aegirine rims. In this hypothesis, aegirine necessarily stopped growing during their migration from the magma chamber to the pegmatites, or it would have resulted in another zonation in the magmatic core. Our second hypothesis is that aegirine core and primary zirconosilicates grew at the same time. In this case the conclusions of Jones and Peckett (1981) do not apply. This may be because their study was based on rocks from 
the magmatic chamber of Ilímaussaq which had plenty of time to equilibrate during crystallization, whereas our study is based on pegmatites, which crystallize quickly. Anyhow, in this hypothesis the competition between the two minerals resulted in the preference of $\mathrm{Zr}$ to go into primary zirconosilicates, but because of the high content of $\mathrm{Zr}$ in the melt and its low mobility (Duggan 1988), affinity for aegirine was still high enough to enrich it up to the $2 \mathrm{wt} \%$ that we have measured. The subsequent hydrothermal stage is similar to the one in our previous hypothesis, with higher $\mathrm{Zr}$ uptake by zircon rather than by zirconosilicates accounting for the decrease in $\mathrm{Zr}$ concentration in aegirine rims. A similar behavior was observed for Sn and is most likely due to a similar phenomenon. No Sn-based mineral was found in pseudomorphs, but $\mathrm{Sn}^{4+}$ can easily enter in the composition of secondary Ti-oxides because its radius is similar to the $\mathrm{Ti}^{4+}$ ion in eight-fold coordination (Shannon 1976). In addition, Sn is known to have a high solubility in Cl-rich fluids (e.g. Keppler and Wyllie 1991), making it easily mobilized. This results in a much higher Sn content in the magmatic zone A than in the rims of aegirine. At Amis, amphibole in pegmatite as well as aegirine are both enriched in $\mathrm{Sn}, \mathrm{Zn}$ and $\mathrm{Pb}$ in comparison with the other complexes of this study (Fig 7g). Ambohimirahavavy and Manongarivo have similar trace elements concentration (Fig 7g) and formed in the same geological context, a few km away from each other. Both amphibole and pyroxene from Khan Bogd have low trace elements concentrations. All these observations tend to indicate that the variations of absolute concentration in $\mathrm{REE}, \mathrm{Zn}, \mathrm{Sn}, \mathrm{Zr}, \mathrm{U}$ and $\mathrm{Pb}$ between aegirine crystals of the 6 complexes (Fig 7g), similarly to amphiboles, likely reflect parent melt compositions.

\subsection{2. $\quad$ Sector zoning}

Sector zoning occurs in the most outer rims in type-I aegirine, involves variations in $\mathrm{Ti}, \mathrm{Ca}, \mathrm{Fe}$ and REE, and was observed in all complexes. Many explanations have been invoked as to the origin of sector zoning, and the latest agree on the fact that it is linked to a crystal growth faster than element diffusion rates (Ubide et al. 2019). If this condition is respected, it will result a disequilibrium between the different crystal faces that will not all incorporate the same elements as it normally would (Strong 1969; Ferguson 1973; Larsen 1981). Elements are however incorporated on the different crystal faces in a matter so that charge balance is respected (Ubide et al. 2019). The crystallization rate could also impact the size of protosites (partially formed site on the surface of a growing crystal), which are in equilibrium with the crystallizing environment, and preferentially incorporate elements depending on their charge/radius ratio. If the growth rate is higher than ionic diffusion in the crystal, the protosites will not have enough time to re-equilibrate in size and incorporate different elements on the 
different faces of the crystal (Nakamura 1973). This higher growth rate is likely related to a lower temperature due to the change from magmatic to hydrothermal environment (Barkov and Martin 2015). However, these considerations must be taken carefully, as most of the research is based on augite and not aegirine.

Incorporation of Ti in aegirine is uncommon (Rønsbo et al. 1977; Dyulgerov and Platevoet 2006). Many explanations have been evoked: high temperature, low $\mathrm{fO}_{2}$, high $\mathrm{fO}_{2}$, low pressure, high activities of $\mathrm{TiO}_{2}$ and $\mathrm{SiO}_{2}$, high activity of alkalis, or a peculiar chemical composition of the environment such as low $\mathrm{Zr}$ and $\mathrm{Na}$ and high Ca (Ferguson 1973; Flower 1974; Larsen 1976; Rønsbo et al. 1977; Nielsen 1979; Brousse and Rançon 1984; Dyulgerov and Platevoet 2006). In our samples, a high temperature is ruled out as Ti incorporation occurs during the hydrothermal stage. As described in the previous section, $\mathrm{Zr}$ and $\mathrm{Ca}$ concentration are low in the crystallizing environment, and $\mathrm{Na}$ is high. Hence, and in accordance with Dyulgerov and Platevoet (2006), Larsen (1976), and Flower (1974), we suggest that in our rocks the incorporation of Ti into hydrothermal aegirine is favored by a high activity of $\mathrm{Na}$ and the low availability of Zr. Titanium may have been provided by the alteration of magmatic Ti-bearing minerals, such as astrophyllite (found at Manongarivo, Strange Lake, Khan Bogd and Amis, Fig 4a) chevkinite-(Ce) (found at Ambohimirahavavy, Manongarivo and Evisa), or others such as narsarsukite, låvenite, and aenigmatite.

\subsubsection{Oscillatory zoning}

Oscillatory zoning is present in both types of aegirine. In type-I, it is found in the sector zoned rims C (crystallographic sector (110)) and D (crystallographic sector (100)) as well as in zone B, intermediate between the core and the rims. Considering that zone B in type-I aegirine is only present in our samples in Khan Bogd, and was locally described in aegirine from the South Gardar Province, South Greenland by Ranløv and Dymek (1991), a general process to explain its formation is difficult to establish. Like zones C and D, zone B is poorer in $\mathrm{Ca}, \mathrm{Zr}$, Hf, Sn and REE than zone A. It is not specifically enriched in any element, but shows oscillatory zoning in Ti and Mn. We believe that zone B development is related to a specificity in the history of the Khan Bogd complex (Kynicky et al. 2011). In this complex, magmatic zone A aegirine would crystallize before or in competition with primary elpidite. At the hydrothermal stage, primary elpidite altered mostly into a secondary hydrated Ca- and REE-rich elpidite (Fig 4i), and zone B grew simultaneously. The uptake of $\mathrm{Ca}$ and $\mathrm{Zr}$ by secondary elpidite from the fluid led to the lower concentration of these elements observed in zone B. The final 
stage, similarly to other complexes, was a more or less extensive pseudomorphism of elpidite and the formation of zones $\mathrm{C}$ and $\mathrm{D}$ on aegirine.

Oscillating concentrations in zones $\mathrm{C}$ and $\mathrm{D}$ are most likely produced by autocatalytic surface attachment, or boundary layer effect (Ortoleva et al. 1987; London 2008), which occurs when the crystal growth rate exceeds the diffusion rate of components in the fluid. Consider an initial solution saturated in component A, whose adsorption on the crystal surface is fast. As the adsorption progresses, the interface between the crystal and the solution becomes depleted in component $\mathrm{A}$, and switches to saturation in component $\mathrm{B}$. Component $\mathrm{B}$ is then adsorbed at the surface of the crystal, until the interface crystal-solution becomes saturated in component A again. This process results in a rhythmic but irregular zoning of aegirine crystals in zones $\mathrm{C}$ and $\mathrm{D}$, consistent with a growth in a rapidly changing environment, which is a hydrothermal fluid.

Type-II aegirine either replaces amphibole or forms isolated crystals. Both kinds are found associated with $\mathrm{Fe}$ - and/or Ti- oxides, and are randomly zoned in many elements (Ti, $\mathrm{Ca}, \mathrm{Mn}, \mathrm{Fe}, \mathrm{Hf}, \mathrm{Sn}, \mathrm{Zr}$ at least). The formation of aegirine from amphibole is known to be hydrothermal (e.g. Salvi and Williams-Jones 1990; Gysi et al. 2016). For arfvedsonite, it follows the reaction provided by Salvi and Williams-Jones (1997):

$$
3 \mathrm{Na}_{3} \mathrm{Fe}_{5} \mathrm{Si}_{8} \mathrm{O}_{22}(\mathrm{~F}, \mathrm{OH})_{2}+2 \mathrm{H}_{2} \mathrm{O}=9 \mathrm{NaFeSi}_{2} \mathrm{O}_{6}+2 \mathrm{Fe}_{3} \mathrm{O}_{4}+6 \mathrm{SiO}_{2}+5 \mathrm{H}_{2} .
$$

The released Fe generally forms hematite or magnetite. Considering that zoning patterns are the same for all type-II aegirine crystals and that they are systematically found associated with Fe- and/or Ti- oxides, we consider that they all grew replacing amphibole, totally or partially. Hence, we consider type-II aegirine as hydrothermal.

\subsection{REE behavior in amphiboles and aegirine}

As mentioned in the introduction, amphiboles and pyroxenes, in agreement with their crystal-chemical parameters, can incorporate up to several hundreds of ppm of REE. In addition, their alkaline nature enhances the fractionation of light versus heavy REE through the preferential incorporation of HREE in their structure, resulting in the globally HREE-enriched patterns observed (Fig. 9; Beard et al. 2019). From the amphibole compositions, we know that the melt was rich in F (Table 1). Beard et al. (2020) showed that the more F in the melt, the lower the pyroxene-melt partition coefficient, hence the less REE are incorporated in pyroxene; this affects the LREE more than the HREE and hence contributes to the observed globally HREE-enriched patterns. 

$\mathrm{Zr}$, Hf and Sn, i.e. they are globally enriched in the core compared to the rims, except for Khan Bogd where the opposite is true (Fig 10, Table 3). Given that the REE concentrations in aegirine at Khan Bogd are very low (2-7 ppm for Ce, 4-15 ppm for Y), we believe that this reverse trend is actually not significant (Fig 10). The difference in REE concentration between aegirine zone $\mathrm{A}$ and zones $\mathrm{B}, \mathrm{C}$ and $\mathrm{D}$ is due to the competition between aegirine and zirconosilicates for these elements, during the magmatic stage for zone $\mathrm{A}$, and during the hydrothermal stage for the zones B, C and D. Scandium is sometimes grouped with REE, hence, it is not surprising to observe that, similarly to REE, it is enriched in the core of type-I aegirine. zone B, and with REE-bearing minerals in pseudomorphs (e.g. bastnäsite-(Ce)) for zones C - (110) and D (100). We therefore suggest that it is a competition for REE between aegirine and coprecipitating minerals having each a different REE affinity which explains the variations in REE concentrations among the aegirine core-to-rim zones. REE are also affected by sector zoning and are more concentrated in zone $\mathrm{C}$ than $\mathrm{D}$, along with Ti and Ca. Beard et al. (2019) studied experimentally the fractionation of REE in clinopyroxene in peralkaline melts and showed that the more $\mathrm{Na}$ and less $\mathrm{Ca}$ in M2 site of pyroxene, the smaller the M1 site, and the more HREE are incorporated. In addition, the authors mention that physico-chemical parameters not recorded in the composition of clinopyroxene, such as pressure, also play a significant role in the size of the M1 site. However, this mechanism is well defined only for pyroxenes whose aegirine component is not higher than $50 \%$. In our samples, the substitution $\mathrm{Ca} \rightarrow \mathrm{Na}$ simply cannot be responsible for the zonation observed, as more REE are found in the $\mathrm{C}$ sector, where $\mathrm{Ca}$ concentration is also higher. In addition, in Ca-rich pyroxenes such as diopside and augite, $\mathrm{Ca}$ was not reported to fractionate between sectors (e.g. Ub $\underline{\text { bide }}$ et $\underline{\text { all. }}$. 2019), which is another argument for the occurrence of a different exchange mechanism in our samples. REE with lower or higher atomic numbers, creating a fractionation between the heavy and light REE. To evaluate this process, we calculated the percentages of REE enrichment or depletion from core to rim in type-I pyroxene. To do so, data obtained by LA-ICPMS were assigned either to the core or to the rim, based on their $\mathrm{Zr}$ content and zoning SEM observations. By comparing these two parameters, we were able to determine a threshold value, unique to each complex, below which a given aegirine analysis should be considered as rim, and above which core. These data were averaged out to obtain a single value each for core and rim (Fig 10). Finally, we calculated the extent of loss or enrichment between core and rim for each REE, according to: 
687

where $d$ represents the percentage difference between core and rim, $C$ and $R$ the mean values obtained for core and rim, respectively. Error bars shown in Fig 11 were obtained using common error calculation formulae, namely (Eq. 6) for the mean and (Eq. 7) for the percentage.

$\overline{e r r}=\sqrt{\frac{\sum_{x=1}^{n}\left(e r r_{x}\right)^{2}}{n}}$

$d_{\text {err }}=\frac{C-R}{C} \sqrt{\frac{\operatorname{err}^{2}-\operatorname{err}_{R}^{2}}{(C-R)^{2}}+\frac{\operatorname{err}^{2}}{C^{2}}}$

with $\overline{\text { err }}$ being the mean error, $n$ the number of measurements, $d_{e r r}$ the error on the percentage variation from core to rim, $\operatorname{err}_{C}$ the mean error on core data, and $\operatorname{err}_{R}$ the mean error on rim data. Resulting values indicate an enrichment in that element in the rim compared to the core when positive, while negative ones indicate a depletion (Fig 11).

From the calculation of the percentage of depletion of REE from core to rim (Fig 11) we see that Amis, Manongarivo and Evisa have a trend with a more important depletion of LREE than HREE: from 40-80 \% to 20$40 \%$ depletion, respectively. Ambohimirahavavy shows the opposite trend: around $30 \%$ of LREE depletion for $45 \%$ of HREE depletion. The latter trend is not as obvious as for other complexes, but it is still significant.

\subsection{General model}

We propose a global model of formation for amphiboles and aegirine in pegmatites (Fig 12). During the magmatic stage, two hypotheses remain. In the first one, amphibole and zone A of type-I aegirine grew at early magmatic stage, concentrating $\mathrm{Zr}$ and REE. In the second hypothesis, type-I aegirine core, amphibole and zirconosilicates grew in competition. Most $\mathrm{Zr}$ was incorporated in the zirconosilicates, as well as REE if the primary zirconosilicates was EGM. However, highly differentiated alkaline melts being particularly enriched in $\mathrm{Zr}$ and REE, there is an extra supply in these metals which, combined with a fast crystallization, could be incorporated by the structures of amphiboles and aegirine (Fig 12a).

During the orthomagmatic hydrothermal stage, amphiboles did not grow anymore, and type-I aegirine was in competition with secondary $\mathrm{Zr}$ - and REE-bearing minerals (generally zircon and bastnäsite-(Ce)) that formed pseudomorphs after primary zirconosilicates. Since HFSE have much higher affinity for these secondary 
minerals, their concentrations globally decreased in the co-crystallizing aegirine rims. It is also during this stage that type-II aegirine crystals nucleated. Nevertheless, competition does not explain the observed LREE-HREE fractionation. Residual melt, depleted in incompatible elements, likely crystallized late quartz and feldspar.

Given the overwhelming evidence for circulation of an orthomagmatic fluid in all complexes, we propose that fractionation results from variations in fluid composition. From the presence of secondary minerals such as bastnäsite-(Ce) and fluorite, and the study of fluid inclusions at Ambohimirahavavy and Strange Lake (Estrade 2014; Vasyukova et al. 2016), we know that the fluids contained at least the anions $\mathrm{Cl}^{-}, \mathrm{F}^{-}$, and $\mathrm{CO}_{3}{ }^{2-}$. These species have the ability to form stable complexes with the REE, to different extents. $\mathrm{F}^{-}$and $\mathrm{CO}_{3}{ }^{2-}$ together are mostly depositional ligands (Migdisov et al. 2016), thus precipitate with REE typically forming the LREEbearing bastnäsite-(Ce). On the other hand, $\mathrm{Cl}^{-}$is a weak but abundant ligand that can transport LREE more easily than the heavy ones (Migdisov et al. 2016). If present as a transporting ligand, $\mathrm{F}^{-}$also transports more LREE than HREE (Beard et al. 2020). We can thus infer that, depending on the relative concentrations of each ligand, fractionation of light vs heavy REE would be specific to each complex (Fig 12b). As long as fluid flow continued, aegirine rims kept growing, although REE incorporation and LREE-HREE fractionation kept diminishing. By the time the hydrothermal stage waned, the two aegirine types were in equilibrium with the pseudomorphs and the partially replaced amphiboles (Fig 12c).

\section{Conclusions}

By comparing amphibole and pyroxene in six alkaline complexes worldwide, our study highlights that despite different geodynamic contexts, mineralogy, and REE enrichment, there is a general crystallization process common to all studied alkaline pegmatites. We believe this process can be generalized to all alkaline $\mathrm{SiO}_{2}$-saturated pegmatites worldwide, with local variations in mineralogy and REE-enrichment and fractionation rates. This crystallization process includes at least two main stages, respectively magmatic and hydrothermal.

From the study of the composition of amphibole and type-I aegirine core, we document the magmatic stage, during which a systematic primary enrichment in REE, HFSE and a LREE-HREE fractionation occurs. This enrichment is common to all complexes and linked to the properties of the extremely differentiated alkaline magma. The enrichment rate, however, differs from one complex to another. The REE fractionation is most 
likely due to crystallographic properties of aegirine and alkali amphiboles that preferentially incorporate HREE and do not represent an inherent property of the melt.

From the study of the texture and composition of type-I aegirine rims and type-II aegirine, we document similarities between complexes during the hydrothermal stage, at which amphiboles stop growing, type-I aegirine grows sector-zoned rims, and type-II aegirine begins replacing amphibole along with $\mathrm{Fe}$ - and Ti-oxides. The drop in REE concentration in hydrothermal aegirine of all complexes shows that REE hydrothermal enrichment is globally less effective than magmatic REE enrichment, but still effective. The observed REE fractionation in all complexes show that hydrothermal fluids also have the ability to fractionate LREE-HREE through their transportation associated with ligands such as $\mathrm{F}^{-}, \mathrm{Cl}^{-}$. The rate of fractionation as well as the amount of mobilized REE depends on the local properties of the circulating fluid(s). These observations show that hydrothermal flow is mandatory in order to enhance the concentration of the REE, and specially HREE, in alkaline pegmatites to ore levels.

\section{$\underline{\text { References }}$}

Ancey M, Bastenaire F, Tixier R (1978) Application des méthodes statistiques en microanalyse. Microanal Microsc Électronique À Balayage 323:11-16

Arzamastsev AA, Arzamastseva LV, Zaraiskii GP (2011) Contact interaction of agpaitic magmas with basement gneisses: an example of the Khibina and Lovozero massifs. Petrology 19:109-133

Barkov AY, Martin RF (2015) Anomalous Cr-rich zones in sector-zoned clinopyroxene macrocrysts in gabbro, Mont Royal, Montreal, Quebec, Canada. Can Mineral 53:895-910

Beard C, van Hinsberg V, Stix J, Wilke M (2020) The effect of fluorine on clinopyroxene / melt trace-element partitioning. Contrib Mineral Petrol. https://doi.org/doi: 10.1007/s00410-020-1672-5

Beard CD, van Hinsberg VJ, Stix J, Wilke M (2019) Clinopyroxene/melt trace element partitioning in sodic alkaline magmas. J Petrol. https://doi.org/10.1093/petrology/egz052

Boily M, Williams-Jones AE (1994) The role of magmatic and hydrothermal processes in the chemical evolution of the Strange Lake plutonic complex, Quebec-Labrador. Contrib Mineral Petrol 118:33-47

Bonin B (1988) Peralkaline granites in Corsica: some petrological and geochemical constraints. Rendiconti Della Soc Ital Mineral E Petrol 73:1191-1194

Bonin B (2007) A-type granites and related rocks: evolution of a concept, problems and prospects. Lithos 97:129

Bonin B (1990) Les granites des complexes annulaires, BRGM. Office des publications universitaires

Bonin B, Grelou-Orsini C, Vialette Y (1978) Age, origin and evolution of the anorogenic complex of Evisa (Corsica): A K-Li-Rb-Sr study. Contrib Mineral Petrol 65:425-432 
Bonin B, Platevoet B, Poitrasson F, Renna MR (2008) Eurogranites-IGCP510 2008 Joint Field-meetingAlkaline The Permian-Triassic A-type Volcanic-Plutonic Igneous Suite of Corsica. In: 33th International Geological Congress in Oslo, Norway Convention Centre, Lillestrom, Norway

Borst AM, Friis H, Andersen T, et al (2016) Zirconosilicates in the kakortokites of the Ilímaussaq complex, South Greenland: Implications for fluid evolution and high-field-strength and rare-earth element mineralization in agpaitic systems. Mineral Mag 80:5-30

Bottazzi P, Tiepolo M, Vannucci R, et al (1999) Distinct site preferences for heavy and light REE in amphibole and the prediction of Amph/L D REE. Contrib Mineral Petrol 137:36-45

Brousse R, Rançon JP (1984) Crystallization trends of pyroxenes from agpaitic phonolites (Cantal, France). Mineral Mag 48:39-45

Chakhmouradian AR, Wall F (2012) Rare earth elements: minerals, mines, magnets (and more). Elements 8:333-340

Chakhmouradian AR, Zaitsev AN (2012) Rare earth mineralization in igneous rocks: sources and processes. Elements 8:347-353

Chengyu W, Dianhao H, Zhongxun G (1990) REE Geochemistry in the Weathered Crust of Granites, Longnan Area, Jiangxi Province. Acta Geol Sin - Engl Ed 3:193-209. https://doi.org/10.1111/j.17556724.1990.mp3002006.x

Cocherie A, Rossi P, Fanning CM, Guerrot C (2005) Comparative use of TIMS and SHRIMP for U-Pb zircon dating of A-type granites and mafic tholeiitic layered complexes and dykes from the Corsican Batholith (France). Lithos 82:185-219

Coint N, Barnes CG, Yoshinobu AS, et al (2013) Use of trace element abundances in augite and hornblende to determine the size, connectivity, timing, and evolution of magma batches in a tilted batholith. Geosphere 9:1747-1765

Cucciniello C, Tucker RD, Jourdan F, et al (2016) The age and petrogenesis of alkaline magmatism in the Ampasindava Peninsula and Nosy Be archipelago, northern Madagascar | SpringerLink. Mineral Petrol 110:309-331. https://doi.org/10.1007/s00710-015-0387-1

Currie KL (1985) An unusual peralkaline granite near lac Brisson, Quebec-Labrador. Curr Res 73-80

Deer WA, Howie RA, Zussman J (1997a) Rock-Forming Minerals: Single-chain Silicates, Volume $2 A$. Geological Society of London

Deer WA, Howie RA, Zussman J (1997b) Rock-forming Minerals: Double-Chain Silicates, Volume 2 B. Geological Society of London

Diehl M (1990) Geology, mineralogy, geochemistry and hydrothermal alteration of the Brandberg alkaline complex, Namibia. Geological Survey of Namibia

Donnot M (1963) Côte Nord-Ouest du complexe intrusif alcalin; Ampasindava-Manongarivo

Droop GTR (1987) A general equation for estimating Fe 3+ concentrations in ferromagnesian silicates and oxides from microprobe analyses, using stoichiometric criteria. Mineral Mag 51:431-435

Duggan MB (1988) Zirconium-rich sodic pyroxenes in felsic volcanics from the Warrumbungle Volcano, Central New South Wales, Australia. Mineral Mag 52:491-496

Dyulgerov MM, Platevoet B (2006) Unusual Ti and Zr aegirine-augite and potassic magnesio-arfvedsonite in the peralkaline potassic oversaturated Buhovo-Seslavtzi complex, Bulgaria. Eur J Mineral 18:127-138

Estrade G (2014) Le complexe cénozoïque alcalin d'Ambohimirahavavy à Madagascar : origine, évolution et minéralisations en métaux rares. Toulouse 3 
Estrade G, Béziat D, Salvi S, et al (2014a) Unusual evolution of silica-under-and-oversaturated alkaline rocks in the Cenozoic Ambohimirahavavy Complex (Madagascar): Mineralogical and geochemical evidence. Lithos 206:361-383

Estrade G, Salvi S, Béziat D, et al (2014b) REE and HFSE mineralization in peralkaline granites of the Ambohimirahavavy alkaline complex, Ampasindava peninsula, Madagascar. J Afr Earth Sci 94:141155

Estrade G, Salvi S, Béziat D (2018) Crystallization and destabilization of eudialyte-group minerals in peralkaline granite and pegmatite: a case study from the Ambohimirahavavy complex, Madagascar. Mineral Mag 82:375-399. https://doi.org/10.1180/minmag.2017.081.053

European Commission (2018) Report on Critical Raw Materials and the Circular Economy. http://ec.europa.eu/docsroom/documents/27348. Accessed 25 Apr 2018

Fedele L, Lustrino M, Melluso L, et al (2015) Trace-element partitioning between plagioclase, alkali feldspar, Ti-magnetite, biotite, apatite, and evolved potassic liquids from Campi Flegrei (Southern Italy). Am Mineral 100:233-249

Ferguson AK (1973) On hour-glass sector zoning in clinopyroxene. Mineral Mag 39:321-325. https://doi.org/10.1180/minmag.1973.039.303.08

Flower MF (1974) Phase relations of titan-acmite in the system Na2O-Fe2O3-Al2O3-TiO2-SiO2 at 1000 bars total water pressure. Am Mineral J Earth Planet Mater 59:536-548

Foland KA, Landoll JD, Henderson CMB, Chen J (1993) Formation of cogenetic quartz and nepheline syenites. Geochim Cosmochim Acta 57:697-704. https://doi.org/10.1016/0016-7037(93)90380-F

Goodenough KM, Wall F, Merriman D (2018) The Rare Earth Elements: Demand, Global Resources, and Challenges for Resourcing Future Generations. Nat Resour Res 27:201-216. https://doi.org/10.1007/s11053-017-9336-5

Gowans RM, Lewis WJ, Zalnieriunas RV (2017) Quest Rare Minerals Ltd.: Strange Lake Resource Estimation

Grigor'eva AA, Zubkova NV, Pekov IV, et al (2011) Crystal chemistry of elpidite from Khan Bogdo (Mongolia) and its K-and Rb-exchanged forms. Crystallogr Rep 56:832

Gysi AP, Williams-Jones AE, Collins P (2016) Lithogeochemical vectors for hydrothermal processes in the Strange Lake peralkaline granitic REE-Zr-Nb deposit. Econ Geol 111:1241-1276

Hatch GP (2015) TMR Advanced Rare-Earth Projects Index — Technology Metals Research. http://www.techmetalsresearch.com/metrics-indices/tmr-advanced-rare-earth-projects-index/. Accessed 27 Jun 2018

Hawthorne FC, Oberti R, Cannillo E, et al (2001) Li-bearing arfvedsonitic amphiboles from the Strange Lake peralkaline granite, Quebec. Can Mineral 39:1161-1170

Hawthorne FC, Oberti R, Harlow GE, et al (2012) Nomenclature of the amphibole supergroup. Am Mineral 97:2031-2048

Hawthorne FC, Oberti R, Ungaretti L, et al (1996) Fluor-ferro-leakeite, NaNa2 (Fe2+ 2Fe3+ 2Li) Si8O22F2, a new alkali amphibole from the Canada Pinabete pluton, Questa, New Mexico, USA. Am Mineral $81: 226-228$

Ishihara S, Hua R, Hoshino M, Murakami H (2008) REE abundance and REE minerals in granitic rocks in the Nanling range, Jiangxi Province, southern China, and generation of the REE-rich weathered crust deposits. Resour Geol 58:355-372

Jones AP, Peckett A (1981) Zirconium-bearing aegirines from Motzfeldt, south Greenland. Contrib Mineral Petrol 75:251-255 
Keppler H, Wyllie PJ (1991) Partitioning of Cu, Sn, Mo, W, U, and Th between melt and aqueous fluid in the systems haplogranite-H 2 O- HCl and haplogranite-H 2 O- HF. Contrib Mineral Petrol 109:139-150

Kogarko LN, Williams CT, Woolley AR (2002) Chemical evolution and petrogenetic implications of loparite in the layered, agpaitic Lovozero complex, Kola Peninsula, Russia. Mineral Petrol 74:1-24

Kovalenko VI, Yarmoluyk VV, Sal'nikova EB, et al (2006) Geology, geochronology, and geodynamics of the Khan Bogd alkali granite pluton in southern Mongolia. Geotectonics 40:450-466

Kovalenko VI, Yarmolyuk VV (1995) Endogenous rare metal ore formations and rare metal metallogeny of Mongolia. Econ Geol 90:520-529

Kramm U, Kogarko LN (1994) Nd and Sr isotope signatures of the Khibina and Lovozero agpaitic centres, Kola Alkaline province, Russia. Lithos 32:225-242. https://doi.org/10.1016/0024-4937(94)90041-8

Kynicky J, Chakhmouradian AR, Xu C, et al (2011) Distribution and evolution of zirconium mineralization in peralkaline granites and associated pegmatites of the Khan Bogd complex, southern Mongolia. Can Mineral 49:947-965

Lacroix A (1923) Minéralogie de Madagascar. A. Challamel, éditeur, Librairie maritime et coloniale

Lagarec K, Rancourt DG (1997) Extended Voigt-based analytic lineshape method for determining Ndimensional correlated hyperfine parameter distributions in Mössbauer spectroscopy. Nucl Instrum Methods Phys Res Sect B Beam Interact Mater At 129:266-280

Larsen LM (1976) Clinopyroxenes and coexisting mafic minerals from the alkaline Ilimaussaq intrusion, South Greenland. J Petrol 17:258-290

Larsen LM (1981) Sector zoned aegirine from the Ilímaussaq alkaline intrusion, South Greenland. Contrib Mineral Petrol 76:285-291

Larsen LM, Sørensen H (1987) The Ilímaussaq intrusion-progressive crystallization and formation of layering in an agpaitic magma. Geol Soc Lond Spec Publ 30:473-488

Leake BE, Woolley AR, Arps CE, et al (1997) Nomenclature of amphiboles; report of the Subcommittee on Amphiboles of the International Mineralogical Association Commission on new minerals and mineral names. Mineral Mag 61:295-310

Li X-H, Li W-X, Li Q-L, et al (2010) Petrogenesis and tectonic significance of the 850 Ma Gangbian alkaline complex in South China: evidence from in situ zircon $\mathrm{U}-\mathrm{Pb}$ dating, $\mathrm{Hf}-\mathrm{O}$ isotopes and whole-rock geochemistry. Lithos 114:1-15

Liu Y, Chen Z, Yang Z, et al (2015) Mineralogical and geochemical studies of brecciated ores in the Dalucao REE deposit, Sichuan Province, southwestern China. Ore Geol Rev 70:613-636. https://doi.org/10.1016/j.oregeorev.2015.03.006

Locock AJ (2014) An Excel spreadsheet to classify chemical analyses of amphiboles following the IMA 2012 recommendations. Comput Geosci 62:1-11

London D (2008) Pegmatites. Sp. Pub. 10. Can Miner 347:

Lucas J, Lucas P, Le Mercier T, et al (2014) Rare earths: science, technology, production and use. Elsevier

Mahood GA, Stimac JA (1990) Trace-element partitioning in pantellerites and trachytes. Geochim Cosmochim Acta 54:2257-2276. https://doi.org/10.1016/0016-7037(90)90050-U

Mann U, Marks M, Markl G (2006) Influence of oxygen fugacity on mineral compositions in peralkaline melts: The Katzenbuckel volcano, Southwest Germany. Lithos 91:262-285. https://doi.org/10.1016/j.lithos.2005.09.004 
Marks M, Halama R, Wenzel T, Markl G (2004) Trace element variations in clinopyroxene and amphibole from alkaline to peralkaline syenites and granites: implications for mineral-melt trace-element partitioning. Chem Geol 211:185-215

Marks MA, Markl G (2017) A global review on agpaitic rocks. Earth-Sci Rev 173:229-258

Migdisov A, Williams-Jones AE, Brugger J, Caporuscio FA (2016) Hydrothermal transport, deposition, and fractionation of the REE: Experimental data and thermodynamic calculations. Chem Geol 439:13-42

Miller RM (1983) The Pan-African Damara Orogen of South West Africa/Namibia. Evol Damara Orogen South West Afr

Miller RR (1996) Structural and textural evolution of the Strange Lake peralkaline rare-element (NYF) granitic pegmatite, Quebec-Labrador. Can Mineral 34:349-371

Mollo S, Blundy JD, Giacomoni P, et al (2017) Clinopyroxene-melt element partitioning during interaction between trachybasaltic magma and siliceous crust: Clues from quartzite enclaves at Mt. Etna volcano. Lithos 284-285:447-461. https://doi.org/10.1016/j.lithos.2017.05.003

Moore M, Chakhmouradian AR, Mariano AN, Sidhu R (2015) Evolution of rare-earth mineralization in the Bear Lodge carbonatite, Wyoming: Mineralogical and isotopic evidence. Ore Geol Rev 64:499-521. https://doi.org/10.1016/j.oregeorev.2014.03.015

Morimoto N (1988) Nomenclature of Pyroxenes. Mineral Petrol 39:55-76

Nakamura Y (1973) Origin of sector-zoning of igneous clinopyroxenes. Am Mineral 58:986-990

Nardi LVS, Bitencourt M de F (2009) A-type granitic rocks in post-collisional settings in southernmost Brazil: their classification and relationship with tectonics and magmatic series. Can Mineral 47:1493-1503. https://doi.org/10.3749/canmin.47.6.1493

Nielsen TFD (1979) The occurrence and formation of Ti-aegirines in peralkaline syenites. Contrib Mineral Petrol 69:235-244

Ortoleva P, Merino E, Moore C, Chadam J (1987) Geochemical self-organization I; reaction-transport feedbacks and modeling approach. Am J Sci 287:979-1007

Pennycook SJ, Nellist PD (2011) Scanning Transmission Electron Microscopy: Imaging and Analysis. Springer Science \& Business Media

Piilonen PC, McDonald AM, Lalonde AE (1998) The crystal chemistry of aegirine from Mont Saint-Hilaire, Quebec. Can Mineral 36:779-791

Pillet D, Bonhomme MG, Duthou JL, Chenevoy M (1989) Chronologie Rb/Sr et K/Ar du granite peralcalin du lac Brisson, Labrador central, Nouveau-Québec. Can J Earth Sci 26:328-332

Poitrasson F, Duthou J-L, Pin C (1995) The relationship between petrology and Nd isotopes as evidence for contrasting anorogenic granite genesis: example of the Corsican Province (SE France). J Petrol $36: 1251-1274$

Poitrasson F, Paquette J-L, Montel J-M, et al (1998) Importance of late-magmatic and hydrothermal fluids on the $\mathrm{Sm}-\mathrm{Nd}$ isotope mineral systematics of hypersolvus granites. Chem Geol 146:187-203

Rakotovao S, Rakotondrazafy R, Beziat D, et al (2009) Pétrologie du complexe alcalin cénozoïque d'Ambohimirahavavy, presqu'île d'Ampasindava, nord-ouest de Madagascar. Mada-Géo 13:2-19

Ranløv J, Dymek RF (1991) Compositional zoning in hydrothermal aegirine from fenites in the Proterozoic Gardar Province, South Greenland. Eur J Mineral 837-854. https://doi.org/10.1127/ejm/3/5/0837 
Roelofsen JN (1997) The primary and secondary mafic silicates of two alkaline anorogenic complexes: Strange Lake (Quebec-Labrador) and Amba Dongar (Gujarat, India). PhD Thesis, McGill University Libraries

Rønsbo JG, Pedersen AK, Engell J (1977) Titan-aegirine from early Tertiary ash layers in northern Denmark. Lithos 10:193-204

Salvi S, William-Jones A (1995) Zirconosilicate phase relations in the Strange Lake (Lac Brisson) pluton, Quebec-Labrador, Canada: American Mineralogist. Am Mineral 80:1031-1040. https://doi.org/10.2138/am-1995-9-1019

Salvi S, Williams-Jones AE (1990) The role of hydrothermal processes in the granite-hosted Zr, Y, REE deposit at Strange Lake, Quebec/Labrador: evidence from fluid inclusions. Geochim Cosmochim Acta 54:2403-2418

Salvi S, Williams-Jones AE (2006) Alteration, HFSE mineralisation and hydrocarbon formation in peralkaline igneous systems: Insights from the Strange Lake Pluton, Canada. Lithos 91:19-34

Salvi S, Williams-Jones AE (1996) The role of hydrothermal processes in concentrating high-field strength elements in the Strange Lake peralkaline complex, northeastern Canada. Geochim Cosmochim Acta 60:1917-1932

Salvi S, Williams-Jones AE (1997) Fischer-Tropsch synthesis of hydrocarbons during sub-solidus alteration of the Strange Lake peralkaline granite, Quebec/Labrador, Canada. Geochim Cosmochim Acta 61:83-99

Sanematsu K, Kon Y, Imai A, et al (2013) Geochemical and mineralogical characteristics of ion-adsorption type REE mineralization in Phuket, Thailand. Miner Deposita 48:437-451. https://doi.org/10.1007/s00126011-0380-5

Schmitt AK, Trumbull RB, Dulski P, Emmermann R (2002) Zr-Nb-REE mineralization in peralkaline granites from the Amis Complex, Brandberg (Namibia): evidence for magmatic pre-enrichment from melt inclusions. Econ Geol 97:399-413

Shannon RD (1976) Revised effective ionic radii and systematic studies of interatomic distances in halides and chalcogenides. Acta Crystallogr 32:751-767

Sheard ER, Williams-Jones AE, Heiligmann M, et al (2012) Controls on the Concentration of Zirconium, Niobium, and the Rare Earth Elements in the Thor Lake Rare Metal Deposit, Northwest Territories, Canada. Econ Geol 107:81-104. https://doi.org/10.2113/econgeo.107.1.81

Shearer CK, Larsen LM (1994) Sector-zoned aegirine from the Ilimaussaq alkaline intrusion, South Greenland: Implications for trace-element behavior in pyroxene. Am Mineral 79:340-352

Siegel K, Williams-Jones AE, Stevenson R (2017a) A Nd-and O-isotope study of the REE-rich peralkaline Strange Lake granite: implications for Mesoproterozoic A-type magmatism in the Core Zone (NECanada). Contrib Mineral Petrol 172:54

Siegel K, Williams-Jones AE, van Hinsberg VJ (2017b) The amphiboles of the REE-rich A-type peralkaline Strange Lake pluton-fingerprints of magma evolution. Lithos 288:156-174

Smith MP (2007) Metasomatic silicate chemistry at the Bayan Obo Fe-REE-Nb deposit, Inner Mongolia, China: contrasting chemistry and evolution of fenitising and mineralising fluids. Lithos 93:126-148

Smith MP, Henderson P, Jeffries TER, et al (2004) The rare earth elements and uranium in garnets from the Beinn an Dubhaich Aureole, Skye, Scotland, UK: constraints on processes in a dynamic hydrothermal system. J Petrol 45:457-484

Strong DF (1969) Formation of the hour-glass structure in augite. Mineral Mag 37:472-479

Sun S-S, McDonough W (1989) Chemical and isotopic systematics of oceanic basalts: implications for mantle composition and processes. Geol Soc Lond Spec Publ 42:313-345 
Thomas RJ, De Waele B, Schofield DI, et al (2009) Geological evolution of the Neoproterozoic Bemarivo Belt, northern Madagascar. Precambrian Res 172:279-300. https://doi.org/10.1016/j.precamres.2009.04.008

Trail D, Bruce Watson E, Tailby ND (2012) Ce and Eu anomalies in zircon as proxies for the oxidation state of magmas. Geochim Cosmochim Acta 97:70-87. https://doi.org/10.1016/j.gca.2012.08.032

U. S. Geological Survey (2019) Rare Earths Statistics and Information. In: Miner. Commod. Summ. https://www.usgs.gov/centers/nmic/rare-earths-statistics-and-information. Accessed 28 Aug 2019

Ubide T, McKenna CA, Chew DM, Kamber BS (2015) High-resolution LA-ICP-MS trace element mapping of igneous minerals: In search of magma histories. Chem Geol 409:157-168. https://doi.org/10.1016/j.chemgeo.2015.05.020

Ubide T, Mollo S, Zhao J, et al (2019) Sector-zoned clinopyroxene as a recorder of magma history, eruption triggers, and ascent rates. Geochim Cosmochim Acta 251:265-283. https://doi.org/10.1016/j.gca.2019.02.021

Vasyukova O, Williams-Jones A (2020) Partial melting, fractional crystallisation, liquid immiscibility and hydrothermal mobilisation-A 'Recipe'for the formation of economic A-Type granite-hosted HFSE deposits. Lithos 356:105300

Vasyukova O, Williams-Jones AE (2014) Fluoride-silicate melt immiscibility and its role in REE ore formation: Evidence from the Strange Lake rare metal deposit, Québec-Labrador, Canada. Geochim Cosmochim Acta 139:110-130

Vasyukova OV, Williams-Jones AE (2019) Closed system fluid-mineral-mediated trace element behaviour in peralkaline rare metal pegmatites: Evidence from Strange Lake. Chem Geol 505:86-99

Vasyukova OV, Williams-Jones AE, Blamey NJF (2016) Fluid evolution in the Strange Lake granitic pluton, Canada: Implications for HFSE mobilisation. Chem Geol 444:83-100

Veksler IV, Dorfman AM, Dulski P, et al (2012) Partitioning of elements between silicate melt and immiscible fluoride, chloride, carbonate, phosphate and sulfate melts, with implications to the origin of natrocarbonatite. Geochim Cosmochim Acta 79:20-40. https://doi.org/10.1016/j.gca.2011.11.035

Wang Q, Deng J, Liu X, et al (2010) Discovery of the REE minerals and its geological significance in the Quyang bauxite deposit, West Guangxi, China. J Asian Earth Sci 39:701-712. https://doi.org/10.1016/j.jseaes.2010.05.005

William-Jones AE, Migdisov AA, Samson IM (2012) Hydrothermal mobilisation of the Rare Earth Elements-a Tale of" Ceria" and" Yttria. Elements 8:355-360

Xu C, Kynickỳ J, Smith MP, et al (2017) Origin of heavy rare earth mineralization in South China. Nat Commun 8:14598

Yang X-M, Yang X-Y, Zheng Y-F, Le Bas MJ (2003) A rare earth element-rich carbonatite dyke at Bayan Obo, Inner Mongolia, North China. Mineral Petrol 78:93-110

Zaitsev AN, Terry Williams C, Jeffries TE, et al (2014) Rare earth elements in phoscorites and carbonatites of the Devonian Kola Alkaline Province, Russia: Examples from Kovdor, Khibina, Vuoriyarvi and Turiy Mys complexes. Ore Geol Rev 61:204-225. https://doi.org/10.1016/j.oregeorev.2014.02.002

\section{$\underline{\text { Tables caption }}$}


Table 1 Mean values for the major and trace element composition, obtained by microprobe and LA-ICPMS respectively, of amphiboles from pegmatites and granites from the six complexes. Abbreviations: no.: number of replicates; F-arf: fluoro-arfvedsonite; F-f-f-lea: ferro-ferri-fluoro-leakeite; F-f-kato: ferro-ferri-katophorite; b.d.l: below detection limit; Ambo: Ambohimirahavavy; KB: Khan bogd; M: Manongarivo; SL: Strange Lake

Table 2 Mean values (number of analysis given in bold) for the major and trace element composition, obtained by microprobe and LA-ICPMS respectively, of aegirine from pegmatites and granites from six complexes worldwide in both pegmatites and granites. Granites only comprise type-II aegirine. T I, T II: aegirine type-I, II. Abbreviations: no.: number of replicates; b.d.l: below detection limit; Ambo: Ambohimirahavavy; KB: Khan bogd; M: Manongarivo; SL: Strange Lake

Table 3 Mean composition of cores and rims of type-I aegirine from 5 complexes. Abbreviations: no.: number of replicates; b.d.l: below detection limit; Ambo: Ambohimirahavavy; KB: Khan bogd; M: Manongarivo

\section{Figures caption}

Fig. 1 A logarithmic diagram plotting chondrite-normalized (Sun and McDonough 1989) values of whole-rock $\mathrm{Yb} / \mathrm{La}$ vs $\mathrm{Yb}$ contents for different alkaline complexes worldwide. Five groups are distinguished: alkaline granites, alkaline pegmatites, carbonatites, nepheline syenites, and ion-adsorption deposits. Data are from this study plus from Estrade et al. (2014b), Boily and Williams-Jones (1994), Estrade (2014), Kynicki et al. (2011), Poitrasson et al. (1995), Vasyukova and Williams-Jones (2014), Schmitt et al. (2002), Moore et al. (2015), Yang et al. (2003), Xu et al. (2017), Liu et al. (2015), Zaitsev et al. (2014), Kogarko et al. (2002), Li et al. (2010), Sørensen et al. (1987), Hatch (2015), Sanematsu et al. (2013), Ishihara et al. (2008), Wang et al. (2010), and Chengyu et al. (1990)

Fig. 2 Map localizing the six complexes studied in this paper. The geodynamic context and ages are given below their names in the rectangular boxes 
Fig. 3 Photographs of outcrop or hand samples of pegmatites from the six complexes. Most display a wellmarked layering defined by mineralogy and textural variations

Fig. 4 a Altered astrophyllite from Amis, b REE-bearing pseudomorph (Manongarivo), c Zircon-quartz pseudomorph (Evisa), d Elpidite (Khan Bogd), altered to armstrongite and zircon in its center, e Arfvedsonite replaced by type-II aegirine (Evisa), f A type-I aegirine showing core to rim zoning (Ambohimirahavavy), $\mathbf{g}$ Two tiny fluid inclusions in the rim of a type-I crystal of aegirine (Khan Bogd), h Mineral inclusions contained within the rim of a type-I aegirine (Ambohimirahavavy) that are of the same nature than minerals in REEbearing pseudomorph, i A single crystal of type-II aegirine (Strange Lake), j Zoned amphibole, from katophorite in the core to arfvedsonite in the rims (Evisa), $\mathbf{k}$ A type-I aegirine showing core to rim zoning with zone B (Khan Bogd), $\mathbf{l}$ Zoned amphibole, from arfvedsonite in the core to leakeite in the rims (Evisa). Photographs a, c, e, f, g, $\mathbf{i}$ and $\mathbf{k}$ were taken with an optical microscope; photographs $\mathbf{b}, \mathbf{h}, \mathbf{j}$ and $\mathbf{l}$ with SEM EDS; and $\mathbf{d}$ with optical cathodoluminescence. pseudom: pseudomorph; zrn: zircon; aeg: aegirine; amph: amphiboles; qtz: quartz; afs: alkali feldspar; bsn: bastnäsite-(Ce); arf: arfvedsonite; ox: Ti- and Fe-oxides; calh: calciohilairite; CKZ: unidentified $\mathrm{Ca}$ - and K-bearing zirconosilicates; $\mathrm{CMZ}$ : unidentified $\mathrm{Ca}$ - and $\mathrm{Mn}$-bearing zirconosilicates; NbYsil: unidentified Nb- and Y-bearing silicate; arm: armstrongite; elp: elpidite; astr: astrophyllite

Fig. 5 Chemical composition of amphiboles. a, b, $\mathbf{c}$ Ternary diagrams representing amphibole poles for the a Evisa and Manongarivo complexes; b Ambohimirahavavy and Amis complexes; c Khan Bogd and Strange Lake complexes. Poles are plotted as $10 \mathrm{Mg}$ and $10 \mathrm{Ca}$ for a better visualization of the dataset. d Boxplots showing the trace-element composition of amphiboles from the different complexes. Thick black line represents the median, upper and lower boxplot limits the first and third quartile respectively, upper and lower dashed lines are the maximum and minimum values respectively, and the thin black line is the detection limit. Areas are shaded to distinguish data for each complex M: Manongarivo; Amb: Ambohimirahavavy; SL: Strange Lake; KB: Khan Bogd

Fig. 6 Microprobe and LA-ICPMS maps on a type-I aegirine crystal at Ambohimirahavavy. Visible zonations were also found in the other complexes (see Supplementary material). 3 zones are distinguished: the core A, and the sector-zoned rims Cand D. Microprobe maps are in wt\%, and LA-ICPMS maps are in ppm. Limits of 
aegirine on LA-ICPMS maps are blurry because the signal from the crystal and the matrix mix and do not reflect an actual concentration

Fig. 7 Chemical composition of type-I and type-II aegirine crystals. Type-I aegirine is split between core and rim. Core and rim analyses are identified for Type-I aegirine. a, b, $\mathbf{c}$ are for aegirine, (Ti, Zr)-aegirine, and clinoferrosilite; when figures; $\mathbf{d}, \mathbf{e}, \mathbf{f}$ are for aegirine $+(\mathrm{Ti}, \mathrm{Zr})$-aegirine, hedenbergite, and clinoferrosilite. $\mathbf{a}, \mathbf{d}$ complexes Evisa and Manongarivo; b, e complexes Ambohimirahavavy and Amis; c, f Khan Bogd and Strange Lake; g Box diagrams comparing the trace element contents of aegirine from the different complexes. Thick black line represents the median, upper and lower boxplot limits the first and third quartile respectively, upper and lower dashed lines are the maximum and minimum values respectively, and the thin black line is the detection limit. Colours are keyed to the legend given in a-f. Areas are shaded to distinguish data for each complex

Fig. 8 Logarithmic diagrams plotting chondrite-normalized REE composition obtained by LA-ICP-MS for amphiboles (normalization from Sun and McDonough, 1989) for all six complexes

Fig. 9 Logarithmic diagrams plotting chondrite-normalized REE composition obtained by LA-ICPMS for aegirine (normalization from Sun and McDonough, 1989) for all six complexes. Large spectra presents all LAICP-MS analyses for type-I and type-II aegirine, whereas small spectra on the side show an example of analyses performed on a single type-I crystal

Fig. 10 Diagram plotting REE concentration obtained by LA-ICPMS in the core and rim of type-I pyroxene in 5 complexes. The typical analytical error is provided by the cross on the top right corner and is similar for all provided analyses

Fig. 11 Histograms plotting the difference of REE concentration between the core and the rims of type-I aegirine, and thereby REE fractionation from core to rim. Negative values stand for a higher REE concentration 
in the core, and positive ones for a higher concentration in the rims. The rim enrichment in Khan Bogd is an artifact. Calculated error is shown by black lines at the end of the histogram bars

Fig. 12 A schematic illustration of a model for aegirine and amphiboles formation. The arrows signify transfer of elements (in the boxes) to the different minerals from the melt or fluid (light blue), the line thickness is proportional to the amount of transfer, and a dashed line indicates a possible transfer. Ligands in the fluids are also shown. During the early magmatic stage, the competition for $\mathrm{REE}, \mathrm{Zr}, \mathrm{Hf}, \mathrm{Zr}$ and $\mathrm{Sn}$ is low to moderate (depending on the co-presence or not of amphibole, pyroxene and complex zirconosilicate) and allows a relative enrichment in these elements in type-I aegirine and, mostly for REE, in amphibole. During the hydrothermal stage, the competition for these elements is stronger as it involves zircon and REE-bearing minerals; consequently, type-I aegirine rims are globally depleted. Fluids composition leads to a different mobilization of light and heavy REE, originating REE fractionation. Meanwhile, hydrothermal fluids replace amphiboles by type-II secondary aegirine and Fe-Ti-oxides

\section{Electronic Supplementary Material}

Online Resource 1 Text and maps detailing the geological background of all six studied complexes

Online Resource 2 Table of standards used for calibration of EPMA and associated detection limits. Abbreviation: n.a.: not analyzed

Online Resource 3 Table of detection limits for in situ LA-ICPMS measurements

Online Resource 4 Microprobe maps on a type-I aegirine crystal at Amis. 3 zones are distinguished: A, the core rich in $\mathrm{Ca}, \mathrm{Zr}$, Sn, $\mathrm{Hf}$ and poor in $\mathrm{Na}, \mathrm{Fe}$; $\mathrm{C}$, sector zoning rich in $\mathrm{Ti}, \mathrm{Ca}$; and $\mathrm{D}$, sector zoning rich in Fe. The thick line represents limits of the map 
1133 Online Resource 5 Microprobe maps on a type-I aegirine crystal at Evisa. 3 zones are distinguished: A, the 1134 core rich in $\mathrm{Ca}, \mathrm{Zr}, \mathrm{Sn}, \mathrm{Hf}$ and poor in $\mathrm{Na}, \mathrm{Fe}$; $\mathrm{C}$, sector zoning rich in $\mathrm{Ti}, \mathrm{Ca}$; and $\mathrm{D}$, sector zoning rich in Fe. 1135 The thick line represents limits of the map

1136

1137 Online Resource 6 Microprobe maps on a type-I aegirine crystal at Khan Bogd. 4 zones are distinguished: A, 1138 the core rich in $\mathrm{Ca}, \mathrm{Zr}, \mathrm{Sn}, \mathrm{Hf}$ and poor in $\mathrm{Na}, \mathrm{Fe}$; $\mathrm{B} ; \mathrm{C}$, sector zoning rich in $\mathrm{Ti}, \mathrm{Ca}$; and $\mathrm{D}$, sector zoning rich in $1139 \mathrm{Fe}$

1141 Online Resource 7 Microprobe maps on a type-I aegirine crystal at Manongarivo. 3 zones are distinguished: A, 1142 the core rich in $\mathrm{Ca}, \mathrm{Zr}, \mathrm{Sn}, \mathrm{Hf}$ and poor in $\mathrm{Na}, \mathrm{Fe}$; $\mathrm{C}$, sector zoning rich in $\mathrm{Ti}, \mathrm{Ca}$; and $\mathrm{D}$, sector zoning rich in $\mathrm{Fe}$

1144 Online Resource 8 Microprobe maps on a type-II aegirine crystal at Strange Lake. No core-to-rim zoning is 1145 observed, but an oscillatory zoning occurs for most elements 